\title{
The Price Puzzle Revisited: Can the Cost CHANNEL EXPLAIN A RISE IN INFLATION AFTER A MONETARY POLICY SHOCK?
}

\author{
STEFFEN HENZEL \\ OLIVER HÜLSEWIG \\ ERIC MAYER \\ TIMO WOLLMERSHÄUSER
}

CESIFO WORKING PAPER NO. 2039

CATEGORY 6: MONETARY PoliCy AND InTERnAtional FInANCE JULY 2007

An electronic version of the paper may be downloaded

- from the SSRN website:

- from the RePEc website:

www.SSRN.com

- from the CESifo website:

www.RePEc.org

www.CESifo-group.de 


\title{
The Price Puzzle Revisited: CAn the Cost CHANNEL EXPLAIN A RISE IN INFLATION AFTER A MONETARY POLICY SHOCK?
}

\begin{abstract}
This paper explores whether the cost channel solves the price puzzle. We set-up a New Keynesian DSGE model and estimate it for the euro area by adopting a minimum distance approach. Our findings suggest that - under certain parameter restrictions which are not rejected by the data - the cost channel helps to generate an initial rise of inflation after a monetary contraction.
\end{abstract}

JEL Code: C51, E31, E32.

Keywords: price puzzle, New Keynesian model, cost channel, minimum distance estimation.

\author{
Steffen Henzel \\ Ifo Institute for Economic Research \\ at the University of Munich \\ Poschingerstr. 5 \\ 81679 Munich \\ Germany \\ Henzel@ifo.de \\ Eric Mayer \\ University of Würzburg \\ Department of Economics \\ Sanderring 2 \\ 97070 Würzburg \\ Germany \\ Eric.mayer@mail.uni-wuerzburg.de
}

\author{
Oliver Hülsewig \\ Ifo Institute for Economic Research \\ at the University of Munich \\ Poschingerstr. 5 \\ 81679 Munich \\ Germany \\ Huelsewig@ifo.de \\ Timo Wollmershäuser \\ Ifo Institute for Economic Research \\ at the University of Munich \\ Poschingerstr. 5 \\ 81679 Munich \\ Germany \\ Wollmershaeuser@ifo.de
}

June 6, 2007

We thank Alessandro Calza, Barbara Roffia and Silvia Scopel for kindly providing us with the loan rate data. The usual disclaimer applies. 


\section{Introduction}

Vector autoregressive (VAR) models have become a popular tool for analyzing the effects of monetary policy on the aggregate economy. Despite the popularity, VAR models have been criticized as they occasionally display a controversial result, namely a rise in inflation - that prevails at least temporary - after a monetary contraction. Sims (1992) originally commented on this phenomenon, which has been labeled the price puzzle (Eichenbaum, 1992).

In a VAR model, the presence of a price puzzle casts serious doubts on the possibility of properly identifying a monetary policy shock. Sims (1992) points out that central banks focus on a variety of variables useful for forecasting future inflation that are possibly neglected in the econometric specification, which implies that the unexpected part of a monetary policy shock is insufficiently measured. Consequently, the price puzzle should be mitigated once indicators of nascent inflation - such as commodity prices - are additionally accounted for (Sims, 1992; Leeper, Sims and Zha, 1996; Christiano, Eichenbaum and Evans, 1999).

In contrast, Barth and Ramey (2000) refer to the cost channel of monetary policy as an alternative explanation for an increase in inflation after a monetary tightening. The cost channel is operating alongside the interest rate channel - i.e. the standard aggregate demand channel - by stating that firms depend on credit to finance production, which means that their pricing decisions are directly related to credit conditions since marginal production costs are affected by interest rates. Accordingly, a shift of inflation in response to a monetary policy shock is not necessarily evidence for misspecification but follows from a worsening of credit conditions due to an increase in interest rates. ${ }^{1}$

This paper estimates a New Keynesian DSGE model for the euro area with the intention to explore whether the cost channel is capable to explain an initial rise in inflation after a monetary contraction. The model comprises three sectors, namely firms, households and banks, which are assumed to have some monopoly power over prices, wages and interest rates that are all set - as in Calvo (1983) - in a staggered way. The cost channel is accounted for by noting that firms require loans from banks as they are obliged to pre-finance their production,

\footnotetext{
${ }^{1}$ Barth and Ramey (2000) reach this conclusion by exploring industry level data for the U.S. which shows that prices increase after a monetary tightening even if commodity prices are explicitly accounted for. However, the cost channel may be capable to explain an initial shift in inflation after a monetary tightening, but it is hardly capable to explain a price puzzle that lasts for several years.
} 
which implies that price setting, and hence inflation, is directly affected by interest rates. The relevance of the cost channel of monetary transmission is supported by micro-evidence for the euro area that underlines the relative importance of financial costs as a driving factor for price changes. ${ }^{2}$

As in Rotemberg and Woodford (1998) and Christiano, Eichenbaum, and Evans (2005), we estimate the DSGE model by using a minimum distance approach, which comprises two steps. In the first step, we specify a VAR model to generate empirical impulse responses to a monetary policy shock. Even though we explicitly incorporated commodity prices, inflation initially rises after a monetary contraction. In the second step, we estimate the parameters of the DSGE model by matching the theoretical impulse responses as closely as possible to the empirical impulse responses.

Our analysis is closely related to the study of Rabanal (2007), who explores the relevance of the cost channel in the U.S. on the basis of a DSGE model with sticky prices and wages that is estimated by adopting a Bayesian procedure. His results suggest that the cost channel fails as an explanation for the price puzzle as he finds that "the presence of the cost channel is not enough to generate a positive response of inflation after a monetary policy contraction" (Rabanal, 2007, p. 919). An initial rise of inflation is stimulated by an increase in interest rates that enter marginal production costs, but the shift is completely offset by declines in the real wage and the real rental rate of capital, even when wages are set in a staggered way and capital utilization is assumed to be highly variable, which makes the rental rate of capital less volatile. In a similar vein, Christiano, Eichenbaum, and Evans (2005) estimate a general equilibrium model and conclude that the importance of the cost channel in the U.S. is only minor. Even though a price puzzle emerges in the empirical impulse responses they use for minimizing the distance, the cost channel only contributes to explain inflation inertia, which emerges after a monetary contraction, while inflation immediately falls.

Other studies using a single equation approach report empirical evidence for the cost channel that is more promising. For the U.S., Ravenna and Walsh (2006) estimate an augmented New Keynesian Phillips curve by Generalized Method of Moments (GMM) and find that the evolution of inflation is significantly affected

\footnotetext{
${ }^{2}$ In the surveys conducted by the ECB's Inflation Persistence Network (see Fabiani et al., 2005) firms in major euro area countries were asked to assign scores between 4 (greater importance) and 1 (minor importance) to cost factors according to their importance for price adjustments. Financial costs received an average score of 2.1. With 2.6 the average score of labor costs was only slightly higher.
} 
by changes in interest rates. Using a similar approach, Chowdhury, Hoffmann, and Schabert (2006) show that the cost channel is relevant in the U.S. and the U.K., but not in Germany and in Japan, which possibly indicates that the structure of the financial system - a market-based system versus a bank-based system - has an impact on the consequences of monetary policy actions.

Our analysis departs from the work of Rabanal (2007) in several distinctive aspects: (i) instead of modeling banks as neutral conveyors of monetary impulses, we take into account the empirical evidence of a sticky and incomplete pass-through from money market rates to short-term loan rates in the euro area (de Bondt, 2005) and incorporate a banking sector that sets the loan rate according to a Calvo-type staggered price setting approach; (ii) instead of using a full-information Bayesian estimation technique, we explore the VAR-related price puzzle by adopting a minimum distance estimation, which is limited to the response of the model's variables to a monetary policy shock; and (iii) instead of using U.S. data, we apply our model to the euro area, where the financial system is bank-based rather than market-based as in the U.S. ${ }^{3}$

Our findings suggest that the cost channel in the euro area is incapable to produce a price puzzle in an unrestricted regression, but its presence helps to generate an initially concave response of inflation to a monetary contraction. The fall in inflation is retarded in the first quarters following the shock, before it pursues the traditional hump-shaped and convex response, which can be attributed to the sluggish reaction of real marginal costs that comes along with the simultaneous increase in interest rates - i.e. a tightening of credit conditions - and decreases in the real wage and the real rental rate of capital. An immediate increase of inflation only arises by imposing a higher nominal wage rigidity and/or a lower degree of price stickiness. Interestingly, already small deviations from the estimated parameters are sufficient to create the price puzzle, so that the restrictions are not rejected by the data. To our knowledge, this is the first empirical paper showing that the cost channel helps to explain the price puzzle in a general equilibrium framework.

The paper is structured as follows. In Section 2, the New Keynesian model with the cost channel of monetary policy is set out. Section 3 presents the results of the minimum distance estimation, including several checks on weak identifica-

\footnotetext{
${ }^{3}$ In a related study, Rabanal (2003) also explores the effects of the cost channel in the euro area and draws similar conclusions as in Rabanal (2007). Notice however that except for item (iii) our analysis departs likewise from this work.
} 
tion. In Section 4, we discuss the capability of the cost channel to reproduce an immediate increase of inflation after a monetary policy shock. Section 5 summarizes the main findings and concludes.

\section{The Model}

We employ a New Keynesian Model that consists of firms, households and banks. Firms are partitioned into final good producers and a continuum of intermediate good producers which each produce a differentiated type of good by using capital and labor services. Intermediate good producers have some monopoly power over prices that are set in a staggered way as in Calvo (1983). Households obtain utility from consumption and leisure, they supply a differentiated type of labor, own the capital stock and make investment decisions. They decide on their wages, which are also set - similar to prices - in a staggered way. Finally, banks extent loans to firms in an environment of monopolistic competition. They face frictions when choosing their loan rates, which implies that the aggregate loan rate responds sluggishly to a monetary policy shock.

The model builds on the framework of Christiano, Eichenbaum, and Evans (2005), Smets and Wouters (2003), Galí, Gertler, and López-Salido (2001) and Erceg, Henderson, and Levin (2000) by sharing the same kind of nominal and real rigidities. Following Rabanal (2007) we account for a cost channel of monetary policy by assuming that a fraction of firms require loans from banks, as they are obliged to pay their wage bill in advance of selling their product.

\subsection{Final Good Producers}

Final good producers operate under perfect competition. The technology to produce the aggregate final good is given by:

$$
Y_{t}=\left[\int_{0}^{1} Y_{t}^{\frac{\epsilon-1}{\epsilon}}(i) d i\right]^{\frac{\epsilon}{\epsilon-1}}
$$

where $Y_{t}$ is the final good, $Y_{t}(i)$ are the intermediate goods indexed by $i \in(0,1)$, and $\epsilon>1$ is the elasticity of substitution between the different types of goods.

Profit maximization by the final good producers leads to the following demand equation for each intermediate good:

$$
Y_{t}(i)=\left(\frac{P_{t}(i)}{P_{t}}\right)^{-\epsilon} Y_{t}, \text { for all } i \in(0,1),
$$


where $P_{t}$ denotes the price of the final good, which is derived from the zero profit condition in the final good sector:

$$
P_{t}=\left[\int_{0}^{1} P_{t}^{1-\epsilon}(i) d i\right]^{\frac{1}{1-\epsilon}},
$$

and $P_{t}(i)$ is the price of the intermediate goods.

\subsection{Intermediate Good Producers}

Firms indexed by $i \in(0,1)$ operate in an environment of monopolistic competition. Each firm $i$ has access to the technology:

$$
Y_{t}(i)=\tilde{K}_{t}^{\alpha}(i) N_{t}^{1-\alpha}(i)
$$

where $\tilde{K}_{t}(i)$ denotes capital services, which is the effective utilization of the capital stock given by: $\tilde{K}_{t}(i)=u_{t} K_{t-1}(i)$, with $u_{t}$ describing the capital utilization rate, $N_{t}(i)$ denotes labor services and $\alpha \in(0,1)$ is the capital share of output. (Smets and Wouters, 2003).

Nominal profits by firm $i$ are given by

$$
\Pi_{t}^{f i r m}(i)=P_{t}(i) Y_{t}(i)-Q_{t}^{f i r m}(i),
$$

where $Q_{t}^{\text {firm }}(i)$ are nominal production costs. For the mass of firms $i \in[0, \nu]$, which are required to take up loans $L_{t}(i)$ from banks to pay their wage bill $W_{t} N_{t}(i)$, nominal production costs are determined by: $Q_{t}^{\text {firm }}(i)=R_{t}^{L} W_{t} N_{t}(i)+$ $R_{t}^{K} \tilde{K}_{t}(i)$, where the wage rate $W_{t}$, the gross loan rate $R_{t}^{L}$ and the rental rate of capital $R_{t}^{K}$ are taken as given. For the remaining firms nominal production costs are given by: $Q_{t}^{\text {firm }}(i)=W_{t} N_{t}(i)+R_{t}^{K} \tilde{K}_{t}(i)$. Loan repayment by firms occurs at the end of each period.

Firms employ all types of labor $j$ offered by households that are aggregated the following way:

$$
N_{t}(i)=\left[\int_{0}^{1} N_{t}^{\frac{\phi-1}{\phi}}(i, j) d j\right]^{\frac{\phi}{\phi-1}},
$$

where $\phi>1$ is the elasticity of substitution between the different labor types $j$ in production. Each firm obtains the optimal mix of labor by choosing its labor demand schedules. Aggregating across all firms gives the demand for labor of type $j$ :

$$
N_{t}(j)=\left(\frac{W_{t}(j)}{W_{t}}\right)^{-\phi} N_{t}
$$


where $N_{t}=\int_{0}^{1} N_{t}(i) d i$ is aggregate labor, $W_{t}=\left[\int_{0}^{1} W_{t}^{1-\phi}(j) d j\right]^{\frac{1}{1-\phi}}$ represents the aggregate wage index and $W_{t}(j)$ is the wage of labor type $j$.

Firms have market power for their own product. They maximize expected profits using a stochastic discount factor $\Lambda_{t, t+k}$ that is equal to the intertemporal marginal rate of substitution of a representative household as defined below. Profits are distributed to households at the end of each period. We assume that firms make all their decisions prior to the realization of any time $t$ disturbances (Christiano, Eichenbaum, and Evans, 2005). ${ }^{4}$

Firms face price frictions as in Calvo (1983), which implies a staggered price setting. The price level $P_{t}$ is determined in each period as a weighted average of a fraction of firms $1-\theta_{p}$ that resets their prices and a fraction of firms $\theta_{p}$ that leaves their prices unchanged:

$$
P_{t}=\left[\left(1-\theta_{p}\right)\left(P_{t}^{*}\right)^{1-\epsilon}+\theta_{p}\left(P_{t-1}\right)^{1-\epsilon}\right]^{\frac{1}{1-\epsilon}} .
$$

where $P_{t}^{*}$ is the reset price. Firms that reset their prices are further decomposed into a fraction $1-\omega_{p}$ that re-optimize their prices and a fraction $\omega_{p}$ that set their prices by applying an indexation rule to past inflation (Galí, Gertler, and López-Salido, 2001).

Profit maximization by the firms that are allowed to set their price optimally leads to the following first-order condition:

$$
E_{t-1} \sum_{k=0}^{\infty} \theta^{k} \Lambda_{t, t+k} Y_{t+k}(i)\left[P_{t}^{f}(i)-\frac{\epsilon}{\epsilon-1} P_{t+k} \varphi_{t+k}(i)\right]=0
$$

where $P_{t}^{f}(i)$ is the optimal price, $E_{t-1}$ denotes the expectation operator, conditional on the set of information available at time $t-1$, and $\varphi_{t}(i)$ are real marginal costs that are given by:

$$
\varphi_{t}(i)=\left\{\begin{array}{lll}
\frac{1}{\Phi}\left(\frac{R_{t}^{K}}{P_{t}}\right)^{\alpha}\left(\frac{R_{t}^{L} W_{t}}{P_{t}}\right)^{1-\alpha} & \text { for } & i \in[0, \nu] \\
\frac{1}{\Phi}\left(\frac{R_{t}^{K}}{P_{t}}\right)^{\alpha}\left(\frac{W_{t}}{P_{t}}\right)^{1-\alpha} & \text { for } & i \in] \nu, 1]
\end{array}\right.
$$

with $\Phi=\alpha^{\alpha}(1-\alpha)^{1-\alpha}$. The optimal price is related to the expected real marginal costs, i.e. $P_{t}^{f}(i)$ is a mark-up over the weighted expected real marginal costs.

\footnotetext{
${ }^{4}$ This implies that the decisions made by firms at time $t$ are predetermined, which is consistent with the identification restrictions of a empirical VAR model considered below in which output and inflation are prevented from responding contemporaneously to a monetary policy shock.
} 
Finally, the fraction of firms $\omega_{p}$ that reset their prices in each period by indexing to past inflation, set their prices according to: $P_{t}^{b}=P_{t-1}^{*}\left(P_{t-1} / P_{t-2}\right)$ (Galí, Gertler, and López-Salido, 2001), which implies that the evolution of reset prices is given by:

$$
P_{t}^{*}=\left(P_{t}^{f}\right)^{1-\omega_{p}}\left(P_{t}^{b}\right)^{\omega_{p}}
$$

\section{$2.3 \quad$ Households}

There is a continuum of households indexed by $j \in(0,1)$. Households decide on consumption and savings, they supply a differentiated type of labor, own the capital stock and make investment decisions. Household $j$ maximizes its expected lifetime utility:

$$
E_{t-1} \sum_{k=0}^{\infty} \beta^{k} U_{t+k}(j),
$$

where $E_{t-1}$ is the expectation operator, conditional on the information set available at time $t-1$, and $\beta \in(0,1)$ is a discount factor.

Period utility of household $j$ is described by:

$$
U_{t}(j)=\frac{\left(C_{t}(j)-H_{t}\right)^{1-\sigma}}{1-\sigma}-\frac{N_{t}^{1+\eta}(j)}{1+\eta}
$$

where $C_{t}(j)$ denotes consumption expenditures, $\sigma$ is the coefficient of relative risk aversion, $N_{t}(j)$ denotes labor supply and $\eta$ is the elasticity of marginal disutility of labor. $H_{t}$ describes external habits, which depend positively on consumption of the aggregate household sector in period $t-1, H_{t}=h C_{t-1}$.

Household $j$ maximizes its expected lifetime utility subject to the intertemporal budget constraint:

$$
\begin{aligned}
P_{t} C_{t}(j)+P_{t} I_{t}(j)+D_{t}(j)= & W_{t}(j) N_{t}(j)+\left[R_{t}^{K} u_{t}(j)-P_{t} \Psi\left(u_{t}(j)\right)\right] K_{t-1}(j) \\
& +R_{t-1}^{D} D_{t-1}(j)+\operatorname{Div}_{t}(j)
\end{aligned}
$$

the downward sloped demand equation for labor (7) and the capital accumulation equation:

$$
K_{t}(j)=(1-\delta) K_{t-1}(j)+\left[1-S\left(\frac{I_{t}(j)}{I_{t-1}(j)}\right)\right] I_{t}(j)
$$

where $\delta$ describes the capital depreciation rate.

Each household decides on consumption $C_{t}(j)$ and investment $I_{t}(j)$ expenditures, holds deposits $D_{t}(j)$ offered by banks at the gross deposit rate $R_{t}^{D}$ and 
receives income from supplying labor $W_{t}(j) N_{t}(j)$, from renting capital services to firms, which is equal to the return on the capital stock $R_{t}^{K} u_{t}(j) K_{t-1}(j)$ net of the costs arising from changes in the degree of capital utilization $P_{t} \Psi\left(u_{t}(j)\right) K_{t-1}(j)$, and from obtaining dividends $\operatorname{Div}_{t}(j)$ obtained from firms and banks that are distributed at the end of each period. Since capital is predetermined at the beginning of the period, the income from renting out capital services depends on the level of capital $K_{t-1}(j)$, which was installed at the end of the last period, and the capital utilization rate $u_{t}(j)$. The costs of capital utilization are assumed to equal zero when the capital utilization rate is one, i.e. $\Psi(1)=0$ (Smets and Wouters, 2003).

We assume that households have access to state-contingent securities that insure them against variations in household-specific labor income. This ensures that, in a symmetric equilibrium, households are homogenous with respect to consumption and asset holdings (Christiano, Eichenbaum, and Evans, 2005). Moreover, we assume that households make all their decisions - similar to firms - prior to the realization of any time $t$ disturbances.

The evolution of the capital stock as shown in equation (15) accounts for the existence of capital adjustment costs that are introduced through the function $S($.$) , which is increasing and convex. In the steady state it holds that \bar{S}=\bar{S}^{\prime}=0$ and $\bar{S}^{\prime \prime}>0$ (Christiano, Eichenbaum, and Evans, 2005).

Consumption and savings decisions Maximizing the objective function (12) subject to the intertemporal budget constraint (14) with respect to consumption and savings delivers the following first-order conditions:

$$
\begin{gathered}
\lambda_{t}=\left(C_{t}-h C_{t-1}\right)^{-\sigma} \\
\lambda_{t}=\beta E_{t-1}\left[\lambda_{t+1} \frac{R_{t}^{D} P_{t}}{P_{t+1}}\right],
\end{gathered}
$$

where $\lambda_{t}$ is the Lagrange multiplier associated with the intertemporal budget constraint that equals marginal utility of consumption.

Staggered wage setting Following Erceg, Henderson, and Levin (2000), we assume that households set their wages - similar to prices - in a staggered way at random intervals. Only a fraction of households $1-\theta_{w}$ resets their nominal wages in period $t$, while the remaining fraction $\theta_{w}$ leaves their nominal wages 
unchanged. The aggregate wage index satisfies:

$$
W_{t}=\left[\left(1-\theta_{w}\right)\left(W_{t}^{*}\right)^{1-\phi}+\theta_{w} W_{t-1}^{1-\phi}\right]^{\frac{1}{1-\phi}},
$$

where $W_{t}^{*}$ is the newly set wage. Households that reset their wages in each period are further decomposed into a fraction $1-\omega_{w}$ that re-optimize their nominal wages and a fraction $\omega_{w}$ that adjust their nominal wages by applying an indexation rule to past inflation.

Optimizing households choose their wages so as to maximize their objective function (12) subject to the downward sloping demand equation for their type of labor (7). The first-order condition is:

$$
E_{t-1} \sum_{k=0}^{\infty}\left(\beta \theta_{w}\right)^{k} N_{t+k}(j)\left[\frac{\phi}{\phi-1} N_{t+k}^{\eta}(j)-\frac{W_{t}^{f}(j) \lambda_{t+k}}{P_{t+k}}\right]=0,
$$

where $W_{t}^{f}(j)$ denotes the optimal nominal wage.

Households that reset their nominal wages by indexing to past inflation are assumed to set their wages according to: $W_{t}^{b}=W_{t-1}^{*}\left(P_{t-1} / P_{t-2}\right)$. The dynamics of newly set wages is then given by:

$$
W_{t}^{*}=\left(W_{t}^{f}\right)^{1-\omega_{w}}\left(W_{t}^{b}\right)^{\omega_{w}}
$$

Capital and investment decisions Households increase their supply of capital services either by investing in new capital, which takes one period to be installed, or by changing the utilization rate of already installed capital. Both actions are costly in terms of foregone consumption (Smets and Wouters, 2003).

The first-order conditions for the real shadow value of capital, investment and the choice of capital utilization are:

$$
\begin{gathered}
Q_{t}=E_{t-1}\left[\Lambda_{t, t+1}\left(Q_{t+1}(1-\delta)+r_{t+1}^{K} u_{t+1}-\Psi\left(u_{t+1}\right)\right)\right] \\
Q_{t}\left[1-S\left(\frac{I_{t}}{I_{t-1}}\right)\right]+E_{t-1} \Lambda_{t, t+1} Q_{t+1} S^{\prime}\left(\frac{I_{t+1}}{I_{t}}\right)\left(\frac{I_{t+1}}{I_{t}}\right)^{2} \\
=1+Q_{t} S^{\prime}\left(\frac{I_{t}}{I_{t-1}}\right)\left(\frac{I_{t}}{I_{t-1}}\right) \\
r_{t}^{K}=\Psi^{\prime}\left(u_{t}\right),
\end{gathered}
$$

where $Q_{t}$ denotes the real shadow value of installed capital, i.e. Tobin's $Q, \Lambda_{t, t+k}$ describes the stochastic discount factor given by: $\Lambda_{t, t+k}=\beta^{k}\left(\lambda_{t+k} / \lambda_{t}\right)$, and $r_{t}^{K}$ denotes the real rental rate of capital. 


\subsection{Banks}

Banks indexed by $i \in(0,1)$ extend loans to firms in an environment of monopolistic competition. Profits by bank $i$ are given by:

$$
\Pi_{t}^{\text {bank }}(i)=R_{t}^{L}(i) L_{t}(i)-R_{t}^{D} D_{t}(i)-R_{t}^{M} B_{t}(i),
$$

where $L_{t}(i)$ is the loan volume, $R_{t}^{L}(i)$ is the gross loan rate, $D_{t}(i)$ is the level of deposits, $R_{t}^{D}$ is the gross deposit rate, $B_{t}(i)$ is the net position on the money market and $R_{t}^{M}$ is the gross money market rate, which is controlled by the central bank. Profits are distributed to households at the end of each period.

For each bank the balance sheet constraint is:

$$
L_{t}(i)=D_{t}(i)+B_{t}(i)
$$

which relates the loan volume to the level of deposits and the net position on the money market. ${ }^{5}$ Deposits and money market credits are assumed to represent perfect substitutes for refinancing, which implies that the deposit rate always equals the money market rate, i.e. $R_{t}^{D}=R_{t}^{M}$ (Freixas and Rochet, 1997).

As in Carletti, Hartmann, and Spagnolo (2007), we assume that banks offer differentiated loans and compete in their loan rates. The differentiation of loans may emerge from specialization in certain types of lending (e.g. to small/large firms or to different sectors) or in certain geographical areas. Each bank faces a downward sloped loan demand equation:

$$
L_{t}(i)=\left(\frac{R_{t}^{L}(i)}{R_{t}^{L}}\right)^{-\zeta} L_{t}
$$

where $L_{t}$ is the aggregate loan level and $R_{t}^{L}$ is the average gross loan rate. The interest rate elasticity of loan demand is denoted by $\zeta>1$. Equation (25) is derived from the cost minimization problem of intermediate good firms that hold a diversified loan portfolio.

Banks face frictions when setting the loan rate as in Calvo (1983). We assume that a fraction of banks $1-\tau$ re-optimizes the loan rate in each period $t$, while the remaining fraction $\tau$ keeps the loan rate unchanged.

Profit maximization by the banks that are allowed to set their loan rate optimally leads to the following first-order condition:

$$
E_{t} \sum_{k=0}^{\infty} \tau^{k} \Lambda_{t, t+k} L_{t+k}(i)\left[R_{t}^{L *}(i)-\frac{\zeta}{\zeta-1} R_{t+k}^{M}\right]=0,
$$

\footnotetext{
${ }^{5}$ Notice that $B_{t}(i)$ can either be positive or negative depending on whether the bank borrows or lends on net on the interbank money market.
} 
where $R_{t}^{L *}(i)$ is the optimal loan rate and $\Lambda_{t, t+k}$ is the stochastic discount factor. Banks are assumed - in contrast to firms and households - to reset their loan rates in each period after the realization of any disturbances.

Accordingly, the aggregate loan rate evolves according to:

$$
R_{t}^{L}=\left[(1-\tau)\left(R_{t}^{L *}\right)^{1-\zeta}+\tau\left(R_{t-1}^{L}\right)^{1-\zeta}\right]^{\frac{1}{1-\zeta}} .
$$

\subsection{Final Goods Market Equilibrium and Monetary Pol- icy}

The equilibrium in the final goods market is characterized by the equality of production and demand by households for consumption and investment adjusted for the resource costs attached to variable capital utilization:

$$
Y_{t}=C_{t}+I_{t}+\Psi\left(u_{t}\right) K_{t-1}
$$

The market clearing conditions in the capital rental market, the loan market and the labor market require that supply equals demand at the prevailing market prices.

Finally, we assume that the central bank conducts monetary policy by means of an interest rate reaction function that is specified below.

\subsection{The Linearized Model}

We summarize our model by taking a log-linear approximation of the equations (1) to (28) around the symmetric equilibrium steady state with zero inflation. A variable $\hat{X}_{t}$ denotes in the following the log linear deviation from the steady state value: $\hat{X}_{t}=\ln \left(X_{t}\right)-\ln (\bar{X})$, where $\bar{X}$ represents the steady state value.

The dynamics of real output is described by the goods market equilibrium that can be stated as:

$$
\widehat{Y}_{t}=\gamma_{C} \widehat{C}_{t}+\left(1-\gamma_{C}\right) \widehat{I}_{t}+\alpha\left(1-\frac{1}{\epsilon}\right) \widehat{u}_{t}
$$

where $\gamma_{C}=1-\left[\alpha \delta\left(1-\frac{1}{\epsilon}\right) /\left(\frac{1}{\beta}-1+\delta\right)\right]$.

The consumption equation with external habit formation is given by:

$$
\widehat{C}_{t}=\frac{1}{1+h} E_{t-1} \hat{C}_{t+1}+\frac{h}{1+h} \widehat{C}_{t-1}-\frac{1-h}{(1+h) \sigma} E_{t-1}\left(\widehat{R}_{t}^{M}-\pi_{t+1}\right),
$$


where the inflation rate $\pi_{t}$ is defined as $\pi_{t}=\widehat{P}_{t}-\widehat{P}_{t-1}$. Consumption depends on a weighted average of expected future consumption and past consumption, which results from the presence of external habit formation. In the absence of habit formation, i.e. $h=0$, equation (30) collapses to a purely forward looking IS-equation.

The investment equation is given by:

$$
\widehat{I}_{t}=\frac{\beta}{1+\beta} E_{t-1} \widehat{I}_{t+1}+\frac{1}{1+\beta} \widehat{I}_{t-1}+\frac{1}{\bar{S}^{\prime \prime}(1+\beta)} E_{t-1} \widehat{Q}_{t},
$$

which shows that investment has a forward and backward looking component. This hybrid form comes from the particular specification of the investment adjustment cost function, which helps to capture the humped-shaped response of investment to a monetary policy shock (Christiano, Eichenbaum, and Evans, 2005).

The real shadow value of capital evolves according to:

$$
\widehat{Q}_{t}=\beta(1-\delta) E_{t-1} \widehat{Q}_{t+1}+[1-\beta(1-\delta)] E_{t-1} \widehat{r}_{t+1}^{K}-E_{t-1}\left(\widehat{R}_{t}^{M}-\pi_{t+1}\right) .
$$

The current real shadow value of capital depends positively on the expected future real shadow value and the expected future real rental rate of capital and negatively on the ex ante expected real interest rate.

The capital accumulation equation is standard:

$$
\widehat{K}_{t}=(1-\delta) \widehat{K}_{t-1}+\delta \widehat{I}_{t},
$$

implying that the capital stock evaluated at the end of the current period is determined by the previous capital stock and investment expenditures.

The real rental rate of capital is determined by:

$$
\widehat{r}_{t}^{K}=\widehat{Y}_{t}-\widehat{u}_{t}-\widehat{K}_{t-1}+\widehat{\varphi}_{t} .
$$

For the capital utilization equation it holds that:

$$
\widehat{u}_{t}=\psi \widehat{r}_{t}^{K},
$$

where $\psi=\Psi^{\prime}(1) / \Psi^{\prime \prime}(1)$, assuming that the capital utilization rate equals one in steady state.

The evolution of inflation is described by a hybrid New Keynesian Phillips curve:

$$
\pi_{t}=\gamma_{f} E_{t-1} \pi_{t+1}+\gamma_{b} \pi_{t-1}+\kappa_{p} E_{t-1} \widehat{\varphi}_{t},
$$


where:

$$
\begin{aligned}
\gamma_{f} & =\frac{\beta \theta_{p}}{\theta_{p}+\omega_{p}\left[1-\theta_{p}(1-\beta)\right]} \\
\gamma_{b} & =\frac{\omega_{p}}{\theta_{p}+\omega_{p}\left[1-\theta_{p}(1-\beta)\right]} \\
\kappa_{p} & =\frac{\left(1-\theta_{p}\right)\left(1-\beta \theta_{p}\right)\left(1-\omega_{p}\right)}{\theta_{p}+\omega_{p}\left[1-\theta_{p}(1-\beta)\right]} .
\end{aligned}
$$

The dynamics of the inflation rate is characterized by a forward and backward looking component in addition to the evolution of real marginal costs. For the parameters $\gamma_{f}$ and $\gamma_{b}$ it holds that $\gamma_{f}+\gamma_{b}=1$, for $\beta \rightarrow 1$. The parameter $\kappa$ measures the sensitivity of inflation with respect to real marginal costs.

Real marginal costs are given by:

$$
\widehat{\varphi}_{t}=\alpha \widehat{r}_{t}^{K}+(1-\alpha)\left(\widehat{W}_{t}-\widehat{P}_{t}+\nu \widehat{R}_{t}^{L}\right)
$$

and depend on the real rental rate of capital, real wages and the gross loan rate. The dependency of real marginal costs on the gross loan rate implies that - as emphasized by the cost channel of monetary policy - cyclical movements in the inflation process arise - inter alia - from deviations of the nominal gross loan rate from its steady state.

The development of nominal wage inflation is determined by the wage setting behavior of households, which implies the following expression:

$$
\begin{aligned}
\Delta \widehat{W}_{t}= & \beta \rho_{1} E_{t-1} \Delta \widehat{W}_{t+1}+\omega_{w} \rho_{1} \Delta \widehat{W}_{t-1}-\beta \theta_{w} \rho_{2} E_{t-1} \pi_{t}+\rho_{2} \pi_{t-1} \\
& +\kappa_{w} E_{t-1}\left[\widehat{M R S}_{t}-\left(\widehat{W}_{t}-\widehat{P}_{t}\right)\right]
\end{aligned}
$$

where:

$$
\begin{aligned}
\rho_{1} & =\frac{\theta_{w}}{\omega_{w}+\theta_{w}\left[1-\omega_{w}\left(1-\beta \theta_{w}\right)\right]} \\
\rho_{2} & =\frac{\omega_{w}\left(1-\theta_{w}\right)}{\omega_{w}+\theta_{w}\left[1-\omega_{w}\left(1-\beta \theta_{w}\right)\right]} \\
\kappa_{w} & =\frac{\left(1-\theta_{w}\right)\left(1-\beta \theta_{w}\right)\left(1-\omega_{w}\right)}{\omega_{w}+\theta_{w}\left[1-\omega_{w}\left(1-\beta \theta_{w}\right)\right](1+\eta \phi)}
\end{aligned}
$$

The marginal rate of substitution is described by:

$$
\widehat{M R S}_{t}=\frac{\eta}{1-\alpha} \widehat{Y}_{t}-\frac{\alpha \eta}{1-\alpha}\left(\widehat{u}_{t}+\widehat{K}_{t-1}\right)+\frac{\sigma}{1-h}\left(\widehat{C}_{t}-h \widehat{C}_{t-1}\right) .
$$


Nominal wage inflation is determined by future and past nominal wage inflation, by the current and past inflation rate and by the gap between the marginal rate of substitution and the real wage.

The evolution of the gross loan rate is governed by the following expression:

$$
\widehat{R}_{t}^{L}=\beta \zeta_{1} E_{t} \widehat{R}_{t+1}^{L}+\zeta_{1} \widehat{R}_{t-1}^{L}+\zeta_{2} \widehat{R}_{t}^{M}
$$

where:

$$
\begin{aligned}
\zeta_{1} & =\frac{\tau}{1+\beta \tau^{2}} \\
\zeta_{2} & =\frac{(1-\beta \tau)(1-\tau)}{1+\beta \tau^{2}} .
\end{aligned}
$$

The loan rate is determined by the expected future loan rate, the past loan rate and the money market rate. The pass-through from changes in the money market rate to changes in the loan rate becomes complete, if $\tau$ goes to zero, which implies that $\widehat{R}_{t}^{L}=\widehat{R}_{t}^{M}$.

We close the model by adding the reaction function of the central bank, which is described by the following interest rate rule:

$$
\begin{aligned}
\widehat{R}_{t}^{M} & =\mu_{1} \widehat{R}_{t-1}^{M}+\mu_{2} \widehat{R}_{t-2}^{M}+\left(1-\mu_{1}-\mu_{2}\right) \times \\
& \times\left[\frac{\mu_{\pi}}{4} \sum_{s=0}^{3} \pi_{t-s}+\frac{\mu_{\widehat{Y}}}{2} E_{t}\left(\widehat{Y}_{t+1}+\widehat{Y}_{t+2}\right)\right]+\mu_{\Delta \widehat{Y}} \Delta \widehat{Y}_{t}+z_{t}^{M}
\end{aligned}
$$

where $\mu_{1}$ and $\mu_{2}$ capture the degree of interest rate smoothing, $\mu_{\pi}$ and $\mu_{\widehat{Y}}$ are the reaction coefficients with respect to the present and past inflation rate and the expected future output gap, $\mu_{\Delta \widehat{Y}}$ is the coefficient of the change of the output gap and $z_{t}^{M}$ is the monetary policy shock. The specification of the reaction function is purely empirical, as it delivers interest dynamics that are very close to those observed in the data. ${ }^{6}$

\section{Empirical Results}

Following Christiano, Eichenbaum, and Evans (2005) and Rotemberg and Woodford (1998), we estimate our New Keynesian DSGE model with the cost channel

\footnotetext{
${ }^{6}$ This specification is similar to the one chosen by Smets and Wouters (2003) and Boivin and Giannoni (2006). Instead of determining the policy rule parameters by a minimum distance estimation, we also tried to directly implement the policy rule implied by the estimated VAR model (see for example Christiano, Eichenbaum and Evans, 2005, and Giannoni and Woodford, 2005). Such a rule, however, was very prone to indeterminacy.
} 
for the euro area - the log-linearized equations (29) to (41) - by using a minimum distance approach that comprises two steps. In the first step, we specify a VAR model to generate empirical impulse responses to a monetary policy shock. In the second step, we estimate the parameters of the DSGE model by matching the theoretical impulse responses as closely as possible to the empirical impulse responses.

Certainly, more efficient estimates of the parameters could be obtained by exploiting the response of the economy to other shocks (as for example in Altig et al., 2005). But this potential efficiency gain must be weighted against the cost of additional identifying assumptions that would be required. Moreover, to the extent that the model is unable to explain all the features of the data, the estimation on the basis of responses to monetary shocks allows us to focus the estimation on the relevant empirical features of the data that we seek to explain. In this sense, the estimation approach is robust to the identification of other shocks and to the specification of parts of the model that are not related to the impulse response functions we are interested in.

\subsection{Empirical Impulse Responses}

We employ a VAR model for the euro area of the form:

$$
Z_{t}=A(L) Z_{t-1}+\mu+\varepsilon_{t}
$$

where $Z_{t}$ is a vector of endogenous variables, $A(L)$ describes parameter matrices, $\mu$ is a vector of constant terms and $\varepsilon_{t}$ is a vector of error terms that are assumed to be white noise. The vector $Z_{t}$ comprises the variables:

$$
Z_{t}=\left(\mathrm{GDP}_{t}, \mathrm{INFL}_{t}, \mathrm{WINFL}_{t}, \mathrm{CPINFL}_{t}, \mathrm{RM}_{t}, \mathrm{RL}_{t}\right)^{\prime},
$$

where $\mathrm{GDP}_{t}$ stands for real output, $\mathrm{INFL}_{t}$ for the inflation rate, WINFL $\mathrm{W}_{t}$ for nominal wage inflation, $\mathrm{CPINFL}_{t}$ for commodity price inflation, $\mathrm{RM}_{t}$ for the policy rate of the central bank, which is approximated by a short-term money market rate, and $\mathrm{RL}_{t}$ for the short-term loan rate. The inclusion of CPINFL $L_{t}$ reflects the intention to avoid a priori any possible problems of misspecification (Sims, 1992).

The VAR model is estimated by using quarterly data over the period from 1990 to $2002 .{ }^{7}$ The output level is expressed in logs, while the inflation rate, nominal

\footnotetext{
${ }^{7}$ Appendix A provides a description of the data. Notice that the time period under investigation is determined by the limited availability of the loan rate data.
} 
wage inflation, commodity price inflation and the interest rates are in percent. The vector of constant terms comprises a linear trend and a constant. Choosing a lag length of two ensures that the error terms dismiss signs of autocorrelation and conditional heteroscedasticity. ${ }^{8}$

On the basis of the VAR model we generate impulse responses of the variables in $Z_{t}$ to a monetary policy shock, which is identified by imposing a triangular orthogonalization. The ordering of the variables implies that real output, the inflation rate, nominal wage inflation and commodity price inflation are affected by an innovation in the policy rate with a lag of one quarter, while the loan rate is affected within the same quarter. Figure 1 displays the impulse responses of the variables to a one standard deviation monetary policy shock. The simulation horizon covers 20 quarters. The solid lines denote impulse responses, which are calculated as the Hall mean derived from a bootstrap procedure with 2000 replications (Hall, 1994). The shaded areas are 95\% Hall percentile confidence intervals of the bootstrapped impulse responses. Real output is expressed in percent terms, while all other variables are expressed in units of percentage points at an annual rate.

The impulse responses show that real output declines by degrees following the monetary policy shock, reaching a trough after four quarters, and returns to the baseline value subsequently. ${ }^{9}$ The inflation rate initially increases before it falls significantly after five quarters. The primary shift of inflation reflects a price puzzle, which emerges although commodity price inflation - as an indicator of nascent inflation - is explicitly incorporated. The inflation rate reaches a trough after around eight quarters before it gradually reverts to baseline. Nominal wage inflation declines slowly following the monetary policy shock, getting to a trough after four quarters, and returns to the baseline value subsequently. Commodity price inflation drops instantaneously and recovers afterwards. The money market rate initially increases, then declines temporally and returns to the baseline value subsequently. The loan rate follows a similar pattern as the money market rate, but the reaction is less pronounced, which shows that the pass-through from short-term money market rates to short-term loan rates is incomplete. ${ }^{10}$

We re-estimate the VAR model without commodity price inflation in order

\footnotetext{
${ }^{8}$ We run a variety of tests for misspecification and stability, which are not reported here, but which are available upon request.

${ }^{9}$ Notice that the reaction of real output corresponds with the evolution of the output gap, which is defined by the $\log$-deviation of the output level from a deterministic trend.

${ }^{10}$ We have analyzed this pattern in detail in Hülsewig, Mayer, and Wollmershäuser (2006).
} 
Figure 1: Empirical Impulse Responses to a Monetary Policy Shock
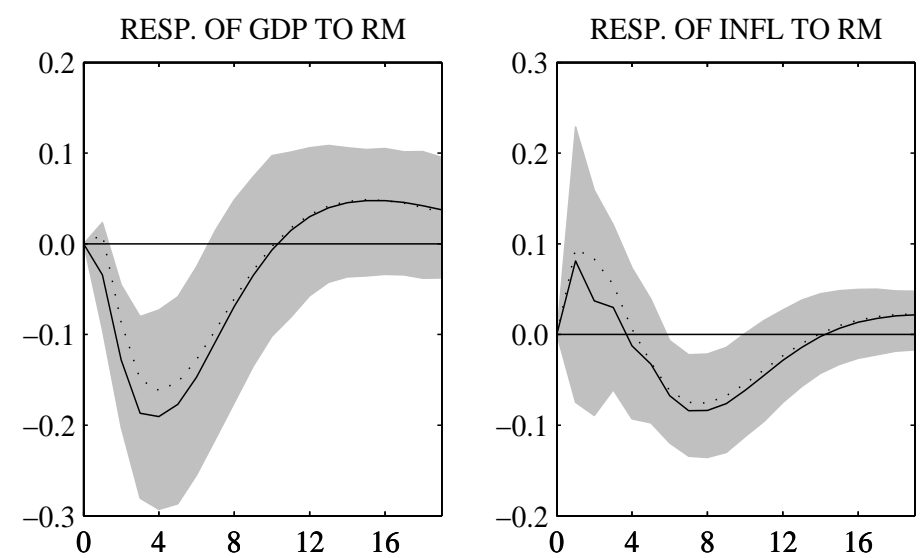

RESP. OF WINFL TO RM

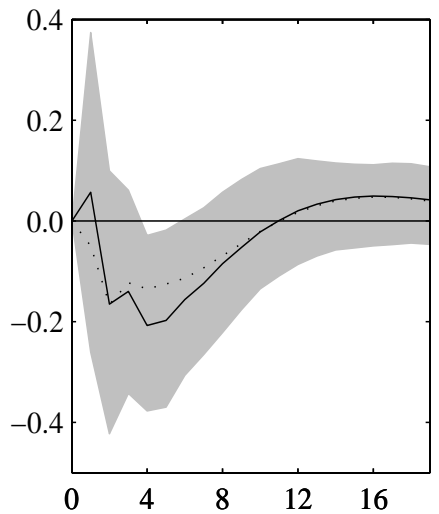

RESP. OF CPINFL TO RM
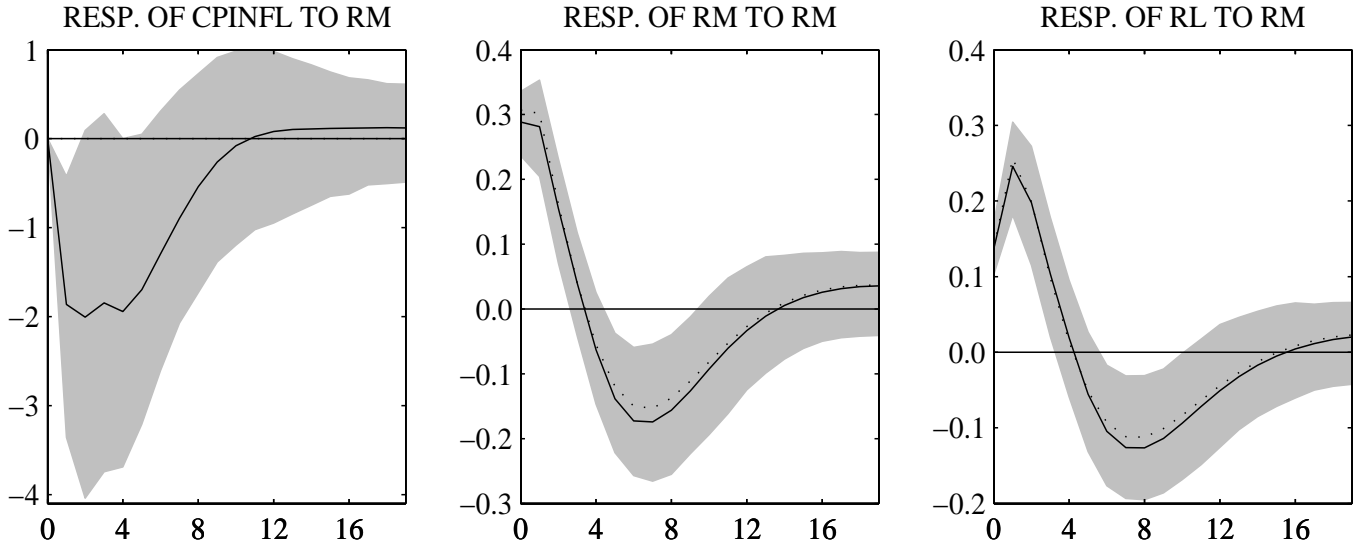

Notes: Orthogonalized impulse responses to a monetary policy shock. The solid lines denote impulse responses, which are calculated as the Hall mean derived from a bootstrap procedure with 2000 replications (Hall, 1994). The shaded areas are 95\% Hall percentile confidence intervals of the bootstrapped impulse responses. Real output is expressed in percent terms, while all other variables are expressed in units of percentage points at an annual rate. The horizontal axis is in quarters. The dotted lines denote the impulse responses to a monetary policy shock from an identically identified VAR that excludes CPINFL $_{t}$ from the vector of endogenous variables. 
to assess the contribution of $\mathrm{CPINFL}_{t}$ to mitigate the price puzzle. The impulse responses are depicted in Figure 1 by the dotted lines, which show that the initial reaction of inflation after the monetary policy shock is more pronounced. This is consistent with the results reported by Sims (1992), which indicate that the inclusion of commodity prices helps to dampen the price puzzle.

Next we turn to the question whether the theoretical model has the ability to replicate a price puzzle following a monetary policy shock. Before we present our results, we briefly discuss the estimation methodology applied.

\subsection{Methodology}

The estimation of our model builds on the following matrix representation:

$$
\Xi_{0} X_{t}=\Xi_{1} X_{t-1}+\Omega_{z} z_{t}+\Omega_{\vartheta} \vartheta_{t}
$$

where $X_{t}$ is the state vector, $z_{t}$ is a vector of shocks and $\vartheta_{t}$ is a vector of expectational errors that satisfy $E_{t} \vartheta_{t+1}=0$ for all $t$. The matrices $\Xi_{0}, \Xi_{1}, \Omega_{z}$ and $\Omega_{\vartheta}$ contain the structural parameters of the model (Sims, 2001).

The closed loop dynamics of the model, which serves as a starting point to generate impulse responses, is given by:

$$
X_{t}(\varrho)=\Theta_{X}(\varrho) X_{t-1}+\Theta_{z}(\varrho) z_{t}
$$

where the rational expectations equilibrium is solved by using the method developed by Sims (2001). ${ }^{11}$ For the matching of the impulse responses, we estimate the following set of parameters:

$$
\varrho=\left(h \bar{S}^{\prime \prime} \psi \theta_{p} \omega_{p} \nu \theta_{w} \omega_{w} \tau \mu_{1} \mu_{2} \mu_{\pi} \mu_{\hat{Y}} \mu_{\Delta \hat{Y}}\right) \text {, }
$$

by minimizing a distance measure between the theoretical impulse responses and the empirical impulse responses.

The remaining parameters are calibrated according to values typically found in related work (see for example Smets and Wouters, 2003, Del Negro et al. 2005, and Leith and Malley, 2005, for estimations of DSGE models of the euro area). The discount factor $\beta$ is fixed to 0.99 , implying a $4 \%$ steady-state real interest rate in a quarterly model. The elasticities of the households' utility function $\sigma$

\footnotetext{
${ }^{11}$ We use the MATLAB files gensys.m, gensysct.m, qzdiv.m, qzdivct.m, and qzswitch.m, which can be downloaded from Chris Sims's web page.
} 
and $\eta$ are both assumed to equal 2. The parameter capturing the mark-up in wage setting $\phi$ is fixed to 3 , which implies a $50 \%$ steady state mark-up. The share of capital in production $\alpha$ is set to 0.3 . The depreciation rate $\delta$ is set to 0.025 per quarter, which implies an annual depreciation of capital equal to $10 \%$. The steady-state mark-up of intermediate good producers over nominal marginal costs is set at 10 per cent, implying that $\epsilon=11$ (see Table 1 for a summary).

Table 1: Calibrated Parameters

\begin{tabular}{lcc}
\hline \hline Parameter & & Calibration \\
\hline Discount factor & $\beta$ & 0.99 \\
Risk aversion & $\sigma$ & 2.00 \\
Labor supply elasticity & $\eta$ & 2.00 \\
Monopoly power of households (wage-setting) & $1 / \phi$ & $1 / 3$ \\
Depreciation rate & $\delta$ & 0.025 \\
Production function & $\alpha$ & 0.3 \\
Monopoly power of firms (price-setting) & $1 / \epsilon$ & $1 / 11$ \\
\hline \hline
\end{tabular}

The need for calibrating a sub-set of parameters is typically encountered in the literature when DSGE models are estimated. One reason for this is that in an unconstrained estimate these parameters are not identified. The decision of which parameters to calibrate, however, is rarely discussed and varies from paper to paper. We therefore propose to distinguish calibrated from estimated parameters by their role for the dynamics of the economy. While the calibrated parameters fully determine the evolution of the flexible price equilibrium of the economy (which takes into account the monopoly power of firms in the intermediate goods market and of households in the labor market), the estimated parameters reflect the inefficiencies resulting from real rigidities $\left(h, \bar{S}^{\prime \prime}, \psi\right)$, nominal frictions $\left(\theta_{p}, \omega_{p}\right.$, $\left.\theta_{w}, \omega_{w}, \tau\right)$ and the cost channel $(\nu)$, and the related policy response $\left(\mu_{1}, \mu_{2}, \mu_{\pi}\right.$, $\left.\mu_{\hat{Y}}, \mu_{\Delta \hat{Y}}\right)$.

The estimator of $\varrho$ minimizes the following distance function (Christiano, Eichenbaum, and Evans, 2005):

$$
J=(\hat{\Gamma}-\Gamma(\varrho))^{\prime} V^{-1}(\hat{\Gamma}-\Gamma(\varrho)),
$$

where $\hat{\Gamma}$ denotes the empirical impulse responses, $\Gamma(\varrho)$ describes the mapping from $\varrho$ to the theoretical impulse responses and $V$ is the weighting matrix with the 
sample variances of $\hat{\Gamma}$ on the diagonal. The weighting matrix assures that those point estimates with a smaller standard deviation are given a higher priority. ${ }^{12,13}$

\subsection{Minimum Distance Estimation}

We estimate the DSGE model by matching impulse responses to a monetary policy shock. ${ }^{14}$ The impulse responses are shown in Figure 2 together with the $95 \%$ error bands. The model replicates the empirical impulse responses reasonably well as all theoretical impulse responses lie within the error bounds. However, two main differences are notable. (i) The inflation rate initially exhibits a concave reaction, which is however never positive. While this response is consistent with the cost channel, its presence is not strong enough to replicate the price puzzle. (ii) The reaction of nominal wage inflation departs in the degree of inertia, which is clearly more pronounced in the theoretical adjustment than in the empirical adjustment.

Before getting into a more detailed discussion on the relevance of the cost channel for explaining the price puzzle, we present the parameter estimates that minimize the distance function $J$. The point estimates for the parameters in the vector $\varrho$ and the related standard errors are summarized in Table 2 . The standard errors are computed using the delta function method. ${ }^{15}$ As the point estimates

\footnotetext{
${ }^{12}$ An efficient estimate of $\varrho$ would require the use of the inverse of the complete variancecovariance matrix $W$ of impulse responses as a weighting matrix. However, as in Giannoni and Woodford (2005) and Boivin and Giannoni (2006), such a weighting matrix appears to hinder the convergence of the optimization routine.

${ }^{13}$ We use the MATLAB optimization routine fmincon, which attempts to find a constrained minimum of a scalar function of several variables, starting at an initial estimate. This is generally referred to as constrained nonlinear optimization. A limitation of the algorithm, which uses a sequential quadratic programming method, is that it might only give local solutions. In Appendix B we check whether our estimates are robust against the choice of the initial conditions

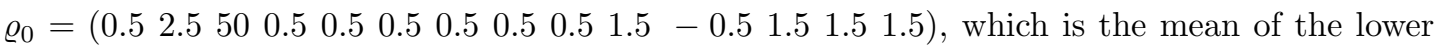

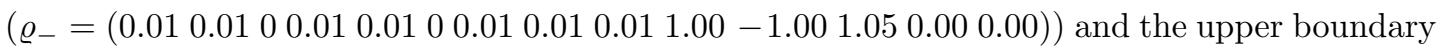

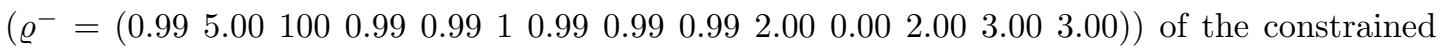
optimization. As a further prerequisite for the reliability of the estimates we take care that the optimization algorithm converges and that the solution of the rational expectations model exists and is unique.

${ }^{14}$ As commodity prices are neglected in the DSGE model, their impulse response function is excluded from the minimum distance estimation.

${ }^{15}$ Following Altig et al. (2005) let $g(\hat{\varrho}, \hat{\Gamma})=J_{\hat{\varrho}}(\hat{\varrho}, \hat{\Gamma})=0$ denote the first order condition associated with the solution to the minimization of (45). Denote the mapping in (45) by $\hat{\varrho}=f(\hat{\Gamma})$. To obtain the sampling variance of the estimator, $\hat{\varrho}$, as a function of the sampling variance of $\hat{\Gamma}$, the delta function method approximates $f(\hat{\Gamma})$ by its linear expansion about the
} 
Figure 2: Model Impulse Responses
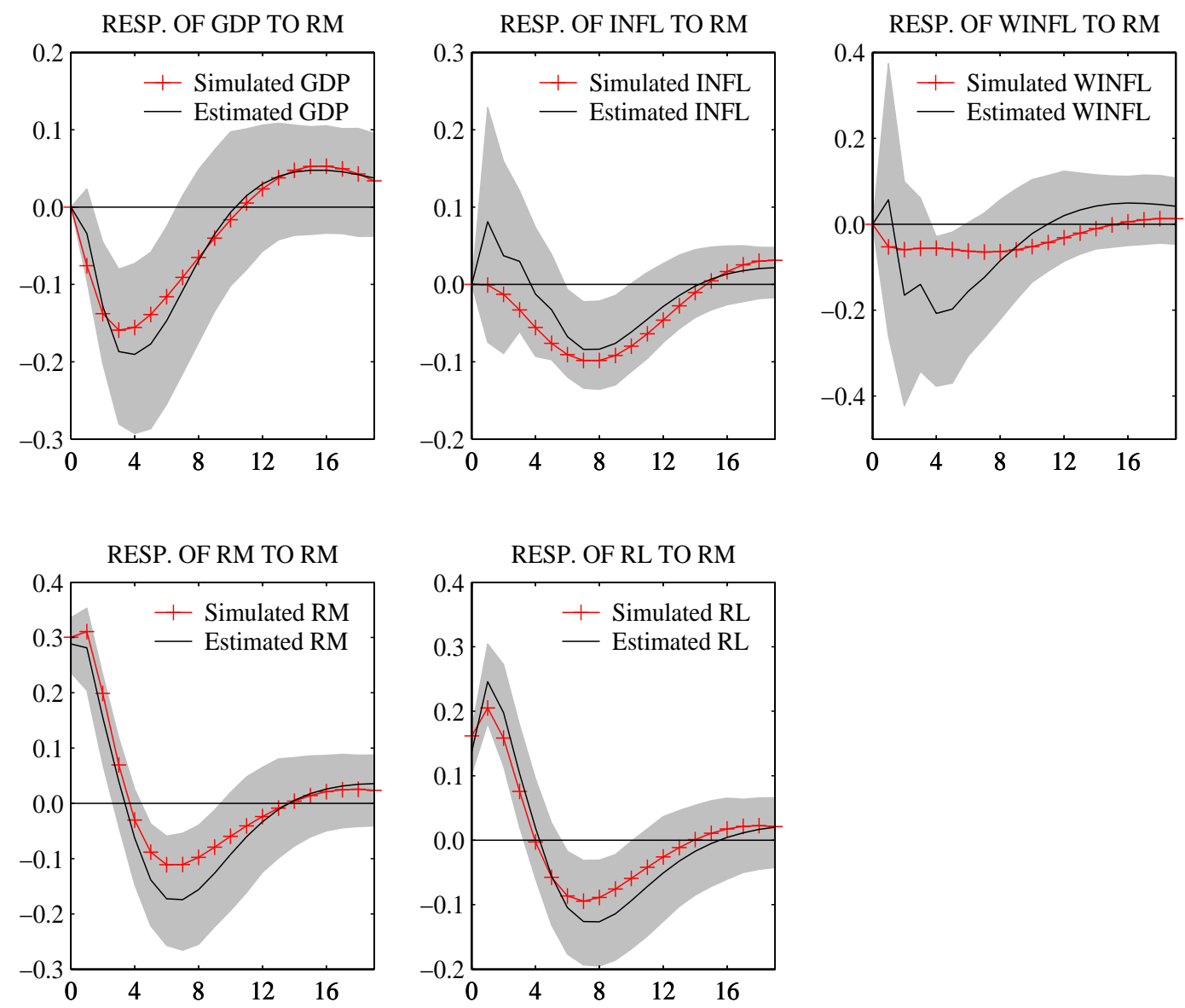

Notes: For the estimated impulse responses see notes to Figure 1.

true value of $\Gamma, \Gamma^{0}$. That is, $f(\hat{\Gamma}) \approx f\left(\Gamma^{0}\right)+f^{\prime}\left(\Gamma^{0}\right)\left(\hat{\Gamma}-\Gamma^{0}\right)$. Here, $f\left(\Gamma^{0}\right)=\varrho^{0}$, where $\varrho^{0}$ is the true value of $\varrho$, by the consistency of our estimator. Then, $\sqrt{N}\left(\varrho_{N}-\varrho^{0}\right)$ is asymptotically normally distributed with mean zero and variance $f^{\prime}\left(\Gamma^{0}\right) W f^{\prime}\left(\Gamma^{0}\right)^{T}$, where $N$ is the number of bootstraps used in the calculation of the empirical impulse responses, $T$ indicates the transposition operator, and $W$ is the asymptotic variance-covariance matrix of $\sqrt{N}\left(\hat{\Gamma}_{N}-\Gamma^{0}\right)$. We use the implicit function theorem to approximate $f^{\prime}\left(\Gamma^{0}\right)$ by $-g_{1}^{-1} g_{2}$, where $g_{1}$ and $g_{2}$ are the partial derivatives of $g$ with respect to $\varrho$ and $\Gamma$, evaluated at $\varrho^{0}$ and $\Gamma^{0}$. In practice, $W$ is replaced by its sample estimate, as are $\varrho^{0}$ and $\Gamma^{0}$ in the expression for $f^{\prime}$. The standard errors reported in Table 2 are the relevant diagonal terms in $f^{\prime}\left(\Gamma^{0}\right) W f^{\prime}\left(\Gamma^{0}\right)^{T}$, after taking square roots and dividing by $\sqrt{N}$. Note that the weighting matrix $V$ in (45) is a diagonal matrix composed of the diagonal elements of $W$. For the calculation of the standard errors we used modified versions of the MATLAB files ComputeStdErrors.m, g1g2Func.m, and MomentFunction.m, which can be downloaded 
for $\psi$ and $\nu$ coincide with the upper boundary of the constrained optimization, we add them to the group of calibrated parameters and therefore do not report standard errors. ${ }^{16}$

Table 2: Parameter Estimates

\begin{tabular}{lccc}
\hline \hline Parameter & & Estimate & Standard error \\
\hline Habit formation & $h$ & 0.91 & 0.09 \\
Investment adjustment costs & $\bar{S}^{\prime \prime}$ & 3.18 & 0.40 \\
Capital utilization variability & $\psi$ & 100 & - \\
Price stickiness & $\theta_{p}$ & 0.56 & 0.19 \\
Rule-of-thumb prices & $\omega_{p}$ & 0.71 & 0.05 \\
Share of cost channel firms & $\nu$ & 1.00 & - \\
Wage stickiness & $\theta_{w}$ & 0.61 & 0.14 \\
Rule-of-thumb wages & $\omega_{w}$ & 0.38 & 0.12 \\
Loan rate stickiness & $\tau$ & 0.41 & 0.03 \\
\hline Taylor rule: smoothing & $\mu_{1}$ & 1.32 & 0.13 \\
Taylor rule: smoothing & $\mu_{2}$ & -0.52 & 0.11 \\
Taylor rule: inflation & $\mu_{\pi}$ & 1.16 & 0.11 \\
Taylor rule: output gap & $\mu_{\hat{Y}}$ & 0.57 & 0.19 \\
Taylor rule: output gap growth rate & $\mu_{\Delta \hat{Y}}$ & 0.58 & 0.12 \\
\hline \hline
\end{tabular}

Notes: The value of the distance function $J$ is 53.70 with a probability of 0.9948 . The probability is calculated by employing a $\chi^{2}-$ distribution with 85 degrees of freedom. The degrees of freedom are calculated as the difference between the total number of estimated observations on the impulse response functions (97) and the number of estimated parameters (12). As the value of the distance function falls below the $1 \%$ critical value of the $\chi^{2}$-distribution, the imposed overidentifying restrictions cannot be rejected.

In the consumption Euler equation the estimated degree of habit formation is substantial and indicates that the response of consumption to an interest rate shock is largely driven by habits. This estimate appears to validate the claim of Rudebusch and Fuhrer (2005) that the degree of forward-looking behavior in consumption is limited (see also Giannoni and Woodford, 2005, and Nelson, Andrés and López-Salido, 2005). Given a calibrated intertemporal elasticity of substitution of $1 / \sigma=1 / 2$ our estimate implies that an expected one percentage

from Lawrence Christiano's web page.

${ }^{16}$ In Appendix B we show that the estimated parameters are properly identified in the constrained parameter space. In order to take into account the uncertainty surrounding the concrete values of the calibrated parameters, we also check the robustness of the estimates for $\varrho$ against variations of the calibrated parameters (see Appendix C). 
point increase in the real short-term interest rate for four quarters has an impact on consumption of round about $0.045 \% .{ }^{17}$

The estimate of the adjustment cost parameter in investment dynamics is somewhat smaller than the value reported by Smets and Wouters (2003) who estimate a value of 5.9. Our estimate of 3.18 implies that investment increases by $0.31 \%$ following a one percent increase in the current price of installed capital. Calibrating the elasticity of capital utilization with respect to the rental rate of capital $\psi$ to 100 is in line with the calibration of Christiano, Eichenbaum, and Evans (2005) and the estimate reported by Rabanal (2007).

The supply side of the model exhibits a considerable degree of stickiness in prices and wages, and additionally reveals a prominent role for backward-looking behavior in price- and wage-setting decisions. For price setters the estimate of $\theta_{p}=0.56$ implies that prices are fixed on average for 2.3 quarters. ${ }^{18}$ This result is at the lower end of estimates reported in other studies for the euro area. Del Negro et. al. (2005) estimate an average price duration of three quarters using full information Bayesian techniques; Galí, Gertler, and López-Salido (2001) report values of round about four quarters using a single equation GMM approach; Welz (2006) who also applies Bayesian techniques to a DSGE model estimates a duration of 6.5 quarters. On the upper end Smets and Wouters (2003) find evidence that price contracts last on average for ten quarters. ${ }^{19}$ Empirical work

\footnotetext{
${ }^{17}$ The interest rate elasticity of consumption can be calculated by iterating the consumption Euler equation (30) forward: $\widehat{C}_{t}=h \widehat{C}_{t-1}-\frac{1-h}{\sigma} E_{t-1} \sum_{i=0}^{\infty}\left(\widehat{R}_{t+i}^{M}-\pi_{t+i+1}\right)$.

${ }^{18}$ The Calvo specification implies that the average duration of fixed prices is computed by $\left(1-\theta_{p}\right)^{-1}$.

${ }^{19}$ Note that the estimates of Smets and Wouters (2003) and Del Negro et. al. (2005) are not strictly comparable to our estimates. While we have specified the Phillips curve as in Galí, Gertler, and López-Salido (2001), Smets and Wouters (2003) and Del Negro et. al. (2005) follow the specification as proposed by Christiano, Eichenbaum, and Evans (2005). In this framework all price setters adjust prices in every period. Thus there is no price stickiness in a strict sense. The parameter $1-\theta_{p}$ in their framework denotes the share of optimizers while $\theta_{p}$ denotes the share of price setters that partially index prices to last periods inflation rate. This means that all price setters adjust prices, and only a fraction of $1-\theta_{p}$ adjusts optimally. Therefore, the average price duration indicates how long it takes on average before being allowed to re-optimize. In the framework applied by Galí, Gertler, and López-Salido (2001) we have true price stickiness in the sense that a fraction of $\theta_{p}$ of price setters is not allowed to change prices at all. The remaining mass of $1-\theta_{p}$ is divided into two subgroups: a fraction $\omega_{p}$ that adjusts prices according to a complete indexation rule, and a fraction $1-\omega_{p}$ that optimizes. The main reason for applying the framework of Galí, Gertler, and López-Salido (2001) instead of the partial indexation framework of Christiano, Eichenbaum, and Evans (2005) is that the
} 
on price setting in the euro area using micro consumer price data also reports relatively low price durations with a median of around 3.5 quarters (see Álvarez et al., 2006, for a summary of recent micro evidence). Comparable studies for the U.S. like Altig et. al. (2005) report much lower average price durations of just 1.6 quarters, which they claim to be more consistent with recent evidence drawn from US micro-data.

Our results additionally indicate that backward-looking price setting behavior plays a prominent role as $71 \%$ of all price adjusters reset their prices in each period by complete indexing to past inflation. The empirical evidence on the degree of partial indexation of prices to past inflation rates in the euro area vary from 0.29 to 0.75 . Leith and Malley (2005) estimated a value of 0.29, while Coenen, McAdam, and Straub (2007) propose to calibrate the degree of indexation to a value of 0.75 .

The share of cost channel firms is 1, implying that all firms consider shortterm financial costs to be relevant for price setting. This value is significantly higher than in Rabanal (2007) who estimated the share of cost channel firms in the U.S. to be 0.15 (with a standard error of 0.13). In the next Section we show that a restriction of $\nu=0$ is rejected by the data.

Wages seem to be as sticky as prices in the euro area with an average wage duration of 2.6 quarters. Rabanal and Rubio-Ramirez (2003) report a smaller estimate with an average duration of 1.2 quarters, while Smets and Wouters (2003) and Leith and Malley (2005) propose value of 4.1 and 7.7, respectively. ${ }^{20}$ Our estimate for $\omega_{p}$ indicates that the share of backward-looking agents among those who adjust wages is $38 \%$. Leith and Malley (2005) who also apply the complete indexation framework report a share of $17 \%$. Using a partial indexation model Smets and Wouters (2003) estimate the degree of wage indexation to be 0.66, while Rabanal and Rubio-Ramirez (2003) report a value of 0.34 .

The significant estimate for $\tau$ reveals that the banking industry plays a meaningful role in propagating monetary shocks. The degree of loan rate stickiness was estimated to be 0.41 , which implies that loan rates are fixed on average for

former better fits the data. Replacing equations (36) and (38) with their partial indexation counterparts (see equations (32) and (33) in Christiano, Eichenbaum, and Evans, 2005) results in a $10 \%$ higher value of the distance function $J$.

${ }^{20}$ Note that for the same reasons as laid out in the previous footnote the estimates are not directly comparable as Smets and Wouters (2003) and Rabanal and Rubio-Ramirez (2003) aggregate wage setters as proposed by Christiano, Eichenbaum, and Evans (2005), while we apply the aggregation framework of Galí, Gertler, and López-Salido (2001). 
1.7 quarters. Thus, stickiness in financial markets is substantially lower than in goods and labor markets. This feature of the model extends earlier findings by Christiano, Eichenbaum, and Evans (2005) and Ravenna and Walsh (2006), who model the banking industry as a neutral conveyor of monetary shocks. Their model of the banking industry can be regarded as a special case of our model with $\tau=0$.

The Taylor rule coefficients display the familiar values. The estimate of the inflation coefficient is 1.16 and the output gap coefficient is 0.57 . In addition we also find evidence for a significant response to the change in the output gap. This finding is in line with Smets and Wouters (2003) and theoretical suggestions of Walsh (2003). The autoregressive interest rate coefficients sum up to 0.80 , indicating a substantial degree of interest rate smoothing, which is reported in most of the literature.

\section{Relevance of the Cost Channel for the Price Puzzle}

According to the traditional aggregate demand channel the initial response of inflation after a monetary contraction should be negative and convex as both, the real rental rate of capital and real wages immediately fall on a convex impulse response function. This result holds irrespective of the concrete parametrization of the theoretical model. Thus, a price puzzle cannot be produced if monetary policy is solely transmitted via the aggregate demand channel. The cost channel counteracts the cost-reducing aggregate demand channel as the loan rate positively affects real marginal costs both, directly (see equation (37)) and indirectly via the real rental rate of capital (see equation (37) in conjunction with equation (34)). If the cost channel is active, the initial response of inflation to a monetary policy shock may turn concave and possibly - depending on the parametrization of the model - positive.

\subsection{A Re-calibration of the Baseline Model}

Even though the VAR model clearly showed that there is a price puzzle in the data, the minimum distance estimation was unsuccessful in finding parameters that replicate the increase in inflation following a positive monetary policy shock in the DSGE model. The purpose of this Section is to uncover those parameters 
in the model that would increase the initial supply-side effects of monetary policy. Figure 3 shows the responses of inflation to a monetary policy shock in the first four quarters following the shock. The solid lines show the impulse responses of the baseline parametrization of the model (see Tables 1 and 2). The dotted and dashed-dotted lines show the impulse responses of the model, in which only the parameter displayed on the top of the graph is altered, while the remaining parameters are fixed at their baseline values.

Figure 3: Re-calibrating the Baseline Model - Impulse Responses of Inflation
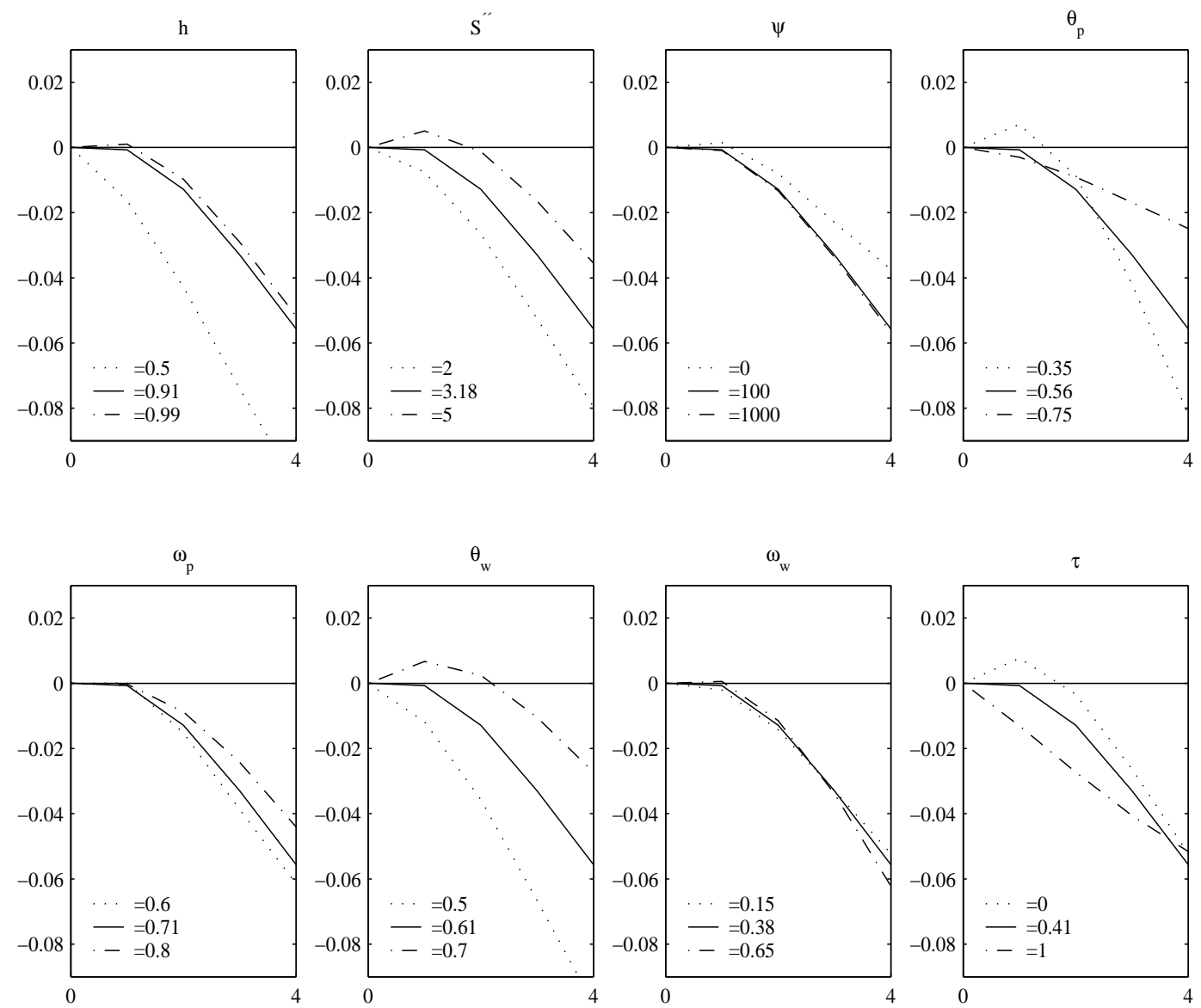

Notes: Responses of inflation to a monetary policy shock in the first four quarters following the shock. The solid lines show the impulse responses of the baseline parametrization of the model (see Tables 1 and 2). The dotted and dashed-dotted lines show the impulse responses of the model, in which only the parameter displayed on the top of the graph is altered, while the remaining parameters are fixed at their baseline values. 
Most of the impulse responses exhibit the concave pattern that indicates the existence of a cost channel. The most "powerful" parameter for creating a price puzzle is the degree of wage rigidity. The higher nominal wage rigidity is, the less pronounced is the decline in real wages after a monetary contraction and the more effective is the cost-augmenting impact of the loan rate. Increasing $\theta_{w}$ to 0.7 (which means that on average wages are adjusted every 3.3 quarters) results in a positive response of inflation in the first two quarters. Note however that the peak of the response is still well below the empirical impulse response which peaks in $t=1$ with an inflation rate equal to 0.08 .

An initial increase in inflation can also be generated by a lower degree of price stickiness $\theta_{p}$. If the flexibility of prices increases relative to the flexibility of wages, the decline in real wages after a monetary contraction becomes smaller, which in turn strengthens the effectiveness of the cost channel. Thus, we come to the same conclusion as Rabanal (2007) who shows that a high real wage stickiness - either caused by a high $\theta_{w}$ or a low $\theta_{p}$ - is essential for the cost channel to explain a price puzzle.

An increase of the investment adjustment costs $\bar{S}^{\prime \prime}$ also contributes to creating the price puzzle. In this case the impact on real marginal costs is rather complex as a higher $\bar{S}^{\prime \prime}$ first of all reduces the impact of Tobin's Q, and hence of the real rental rate of capital, on the households' investment decisions. In essence, the increase of $\bar{S}^{\prime \prime}$ reduces the decline in $\widehat{r}_{t}^{K}$ after a monetary contraction, which creates a bias towards more labor intensive production and retards the decline in real wages. Over all, the effectiveness of the cost channel is strengthened.

The variations of the loan rate stickiness $\tau$ are also of particular interest. In the case of $\tau=1$, the loan rate is unaffected by changes in the money market rate. Thus, the cost channel is shut down and the response of inflation to a monetary policy shock is convex as expected from the demand-side transmission channels. By contrast, in the case of $\tau=0$, banks refrain from smoothing interest rates and the loan rate exactly follows the money market rate. The more pronounced response of the loan rate is then sufficient to overcompensate the fall in the real rental rate of capital and in real wages so that inflation responds positively to a monetary policy shock.

The remaining parameters cannot be used to generate an increase in inflation. While a higher degree of habit formation $h$ only makes the response more concave, changes in the degree of rule-of-thumb price and wage setters, $\omega_{p}$ and $\omega_{w}$, only have negligible short-run effects on the response of inflation. 


\subsection{Restricted Model Estimations}

In order to see whether the re-calibrations are supported by the data, we reestimate the parameters of the DSGE model by imposing restrictions on those parameters, which are important for the cost channel explanation of the price puzzle. Table 3 summarizes the parameter estimates and Figure 4 shows the impulse responses of the inflation rate to a monetary contraction resulting from the restricted model. The first row of the Table shows the parameters, which have been restricted. The figures in bold indicate the value of the restricted parameter that has been imposed on the minimum distance estimation. $J^{r}$ denotes the value of the distance function resulting from the restricted estimation. The $p$-value indicates the probability that the null hypothesis of a valid parameter restriction can be rejected. It is calculated from a distance metric test (see Meier and Müller, 2006) under the assumption that the deviation of the restricted value of the distance function from the unrestricted value of the distance function, $J^{r}-J$ with $J=53.70$ (see Table 2), is asymptotically distributed as $\chi^{2}$ with degrees of freedom equal to the number of restrictions imposed.

Table 3: Parameter Estimates with Restrictions

\begin{tabular}{lcccccccc}
\hline \hline & $\nu$ & $h$ & $\bar{S}^{\prime \prime}$ & $\psi$ & $\theta_{p}$ & $\theta_{w}$ & $\theta_{p} \& \theta_{w}$ & $\tau$ \\
\hline$h$ & 0.99 & $\mathbf{0 . 9 9}$ & 0.86 & 0.92 & 0.94 & 0.93 & 0.94 & 0.89 \\
$\bar{S}^{\prime \prime}$ & 3.75 & 2.42 & $\mathbf{5 . 0 0}$ & 3.25 & 2.70 & 2.43 & 2.48 & 3.33 \\
$\psi$ & 100 & 100 & 100 & $\mathbf{0 . 0 0}$ & 100 & 100 & 100 & 100 \\
$\theta_{p}$ & 0.38 & 0.55 & 0.57 & 0.79 & $\mathbf{0 . 3 5}$ & 0.43 & $\mathbf{0 . 3 5}$ & 0.48 \\
$\omega_{p}$ & 0.74 & 0.71 & 0.71 & 0.76 & 0.71 & 0.72 & 0.71 & 0.72 \\
$\nu$ & $\mathbf{0 . 0 0}$ & 1.00 & 1.00 & 1.00 & 0.72 & 1.00 & 0.83 & 0.79 \\
$\theta_{w}$ & 0.62 & 0.63 & 0.60 & 0.32 & 0.68 & $\mathbf{0 . 7 0}$ & $\mathbf{0 . 7 0}$ & 0.63 \\
$\omega_{w}$ & 0.35 & 0.39 & 0.36 & 0.38 & 0.53 & 0.48 & 0.54 & 0.41 \\
$\tau$ & 0.39 & 0.41 & 0.41 & 0.39 & 0.40 & 0.41 & 0.40 & $\mathbf{0 . 2 5}$ \\
\hline$\mu_{1}$ & 1.34 & 1.32 & 1.32 & 1.47 & 1.34 & 1.32 & 1.33 & 1.30 \\
$\mu_{2}$ & -0.57 & -0.52 & -0.51 & -0.64 & -0.54 & -0.52 & -0.53 & -0.41 \\
$\mu_{\pi}$ & 1.05 & 1.22 & 1.15 & 1.85 & 1.13 & 1.18 & 1.15 & 1.47 \\
$\mu_{\hat{Y}}$ & 0.35 & 0.52 & 0.60 & 0.11 & 0.65 & 0.66 & 0.67 & 2.27 \\
$\mu_{\Delta \hat{Y}}$ & 0.68 & 0.63 & 0.59 & 1.16 & 0.60 & 0.58 & 0.59 & 0.41 \\
\hline$J^{r}$ & 62.16 & 54.24 & 54.17 & 59.40 & 56.45 & 55.55 & 56.61 & 65.87 \\
$p$ & 0.004 & 0.460 & 0.494 & 0.017 & 0.097 & 0.173 & 0.234 & 0.001 \\
\hline \hline
\end{tabular}

The first column of Table 3 is included in order to gain information on the significance of the share of cost channel firms $\nu$. As in the baseline estimation 
the parameter estimate of $\nu$ hit the upper boundary, we were not able to report reliable standard errors. A model without cost channel firms $(\nu=0)$ fails - as expected - to generate a price puzzle and returns a strictly convex response of inflation to a monetary contraction. More importantly, the value of the distance function exceeds the value of the baseline estimation by $16 \%$, implying that the imposed restriction is rejected by the distance metric test at the $1 \%$ level.

Figure 4: Parameter Restrictions - Impulse Responses of Inflation
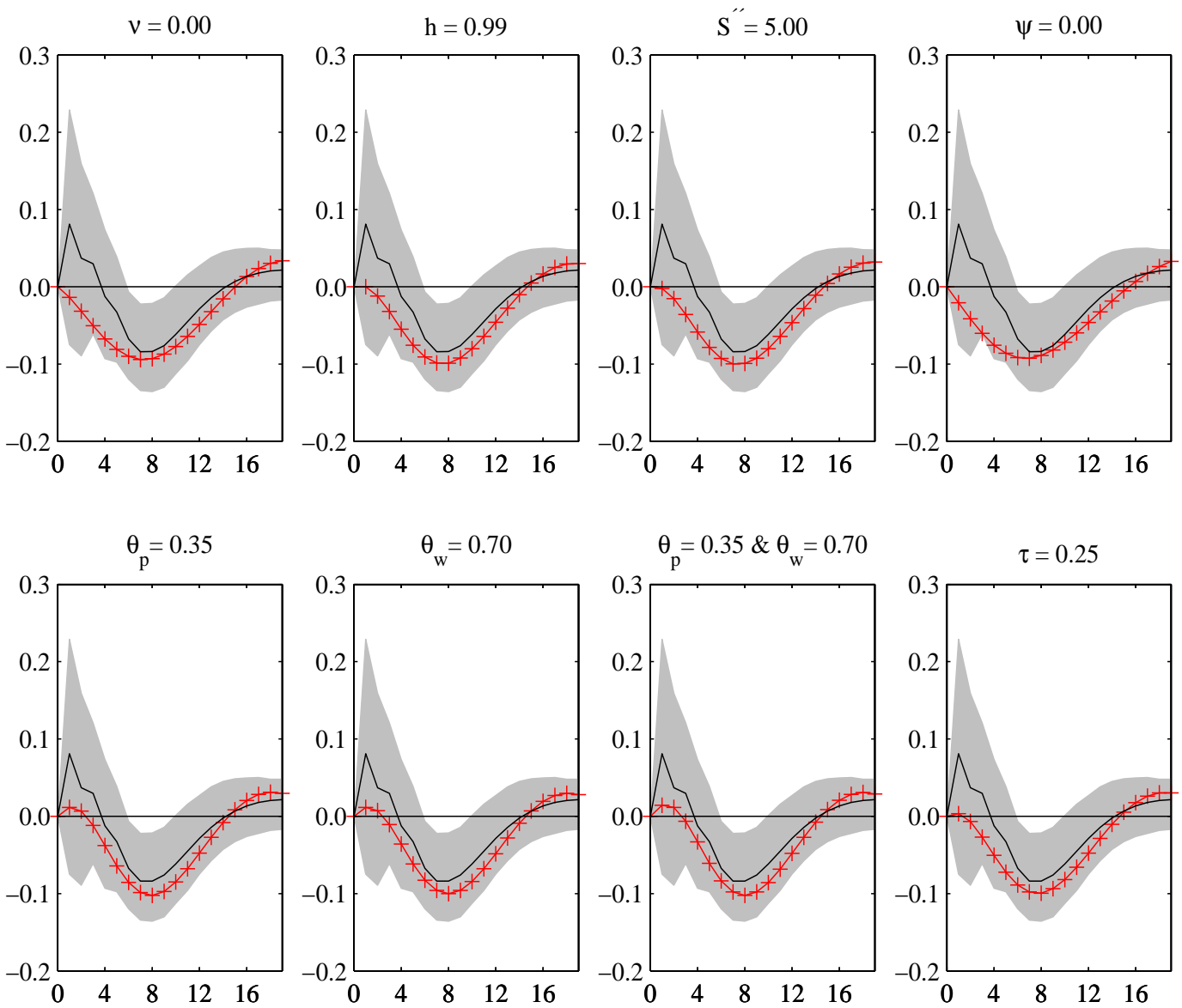

Notes: Responses of inflation to a monetary policy shock. The solid lines and the shaded areas show the empirical impulse responses (see notes to Figure 1). The lines with a cross show the impulse responses of the model, which has been re-estimated with the parameter restriction displayed on the top of the graph (see Table 3 for the corresponding parameter estimates).

Concerning the remaining parameter restrictions, only those imposed on the degree of price and wage stickiness produce a positive response of inflation for two 
quarters without being rejected by the data. Setting $\theta_{p}=0.35$ and/or $\theta_{w}=0.70$ only marginally increases the value of the distance function, so that the distance metric test fails to reject the null hypothesis at the conventional $5 \%$ level. The restriction on the investment adjustment cost parameter $\bar{S}^{\prime \prime}$ is fully compensated by a decrease in the degree of habit formation $h$. Even though the restriction is accepted by the data, the price puzzle obtained in the previous Section (see Figure 3) vanishes. Finally, imposing a lower degree of loan rate stickiness $\tau$ still results in a slight increase of inflation following the monetary contraction; the restriction is, however, rejected by the distance metric test.

\section{Conclusion}

We estimated a New Keynesian DSGE model for the euro area with the intention to explore whether the cost channel is capable to generate an increase in inflation after a monetary contraction. The model incorporated the idea that firms require loans from banks as they are obliged to pre-finance production due to a lack of working capital, which implies that inflation is directly affected by interest rates. We estimated the model by means of a minimum distance approach.

Our findings suggest that the cost channel in the euro area fails to produce a price puzzle in an unrestricted regression, but its presence helps to explain an initially concave response of inflation to a monetary policy contraction. The drop in inflation is retarded in the first quarters after the shock, before it pursues the traditional hump-shaped and convex response, which can be attributed to the sluggish reaction of real marginal costs that comes along with the simultaneous increase in interest rates and decreases in the real wage and the real rental rate of capital. An immediate increase of inflation only arose after incorporating a higher degree of nominal wage rigidity and/or a lower degree of price stickiness. Interestingly, already small deviations from the estimated parameters, which were not rejected by the data, were sufficient to create the price puzzle.

Our analysis is complementary to the work of Rabanal (2007), who investigates the relevance of the cost channel in the U.S. as a possible explanation for the price puzzle using a DSGE model very similar to the one presented here. His results showed that the cost channel not only fails to generate a positive response of inflation after a monetary contraction, but also an initially concave impulse response function. Thus, according to his estimates the traditional demand-side effect of monetary policy dominates the supply-side effect. 
The main difference between the two papers lies in the estimated degree of price and wage stickiness and the estimate for the share of cost channel firms. Rabanal (2007) estimates $\theta_{w}$ at 0.35 (average wage duration of 1.5 quarters) and $\theta_{p}$ at 0.84 (average price duration of 6.25 quarters), which implies that nominal wages are less sticky and prices are more sticky in the U.S. than in the euro area. A lower real wage stickiness considerably weakens the effectiveness of the cost channel relative to the aggregate demand channel, so that the existence of a cost channel cannot be inferred from the impulse response functions anymore. Moreover, according to his estimates cost channel firms only account for $15 \%$ of all intermediate goods producers (with a standard error of 13\%), while our estimates for the euro area implied that all firms depend on credit to finance production. A higher share of cost channel firms clearly increases the importance of financial costs as a driving factor for price changes, which is in accordance with recent micro evidence on the price setting behavior of European firms. An explanation for this result is the widely acknowledged fact, that unlike in the U.S. the financial system in continental European countries is mainly bank-based. We accounted for this difference in the financial structure by explicitly modeling (and estimating) the behavior of financial intermediaries. Instead of modeling banks as neutral conveyors of monetary impulses, we took into account the empirical evidence of sticky and incomplete pass-through from money market rates to short-term loan rates in the euro area and incorporated a banking sector that sets the loan rate according to a Calvo-type staggered price setting approach. According to our estimates short-term loan rates are fixed on average for 1.7 quarters. While this modeling strategy clearly dampens the effectiveness of the cost channel, it is an integral part of a bank-based financial system and has to be jointly interpreted with the estimated high dependency of firms on external finance. 


\section{Appendices}

\section{A Data Base}

The data is taken from the Euro Area Wide Model (AWM, update 5, 1970Q1 2003Q4) - see Fagan, Henry, and Mestre (2001) and www.ecb.org - except for the loan rate data, which has been kindly provided by the ECB. Our sample covers the period from 1990Q1 to 2002Q4 due to the limited availability of a continuous time series for the loan rate.

1. GDP: Log of real GDP, seasonally adjusted (AWM code: YER).

2. INFL: Inflation rate, annualized quarterly change of GDP deflator in percent, seasonally adjusted (AWM code: YED).

3. WINFL: Nominal wage inflation, annualized quarterly change of wage rate in percent (AWM code: WRN)

4. CPINFL: Commodity price inflation, annualized quarterly change of commodity prices in percent (AWM code: COMPR)

5. RM: Short-term nominal interest rate, in percent (AWM code: STN).

6. RL: Retail bank lending rates for loans to enterprizes with maturities up to one year, nominal in percent.

\section{B Identification of the Parameters}

Identifiability is a crucial condition needed for any empirical methodology to deliver sensible estimates and meaningful inference. The parameters are identified if the objective function has a unique minimum and displays sufficient curvature in all relevant dimensions. In a recent paper Canova and Sala (2005) provide some diagnostic tools to detect identification problems related to moment estimators when the objective function measures the distance between empirical and model impulse responses.

For each parameter Figure 5 plots the shape of the objective function in the close neighborhood of the optimum. The horizontal axis depicts the difference between the value of the objective function $J$ as a function of the parameter shown on the top of each graph, conditional on the other parameters being fixed at their 
baseline estimates, and the baseline value of the objective function $(J=53.70)$. For most of the structural parameters the curvature of the objective functions is sufficient to identify a minimum. Therefore, we can conclude that the responses to monetary policy shocks are very informative in that they can be used to identify most of the structural parameters.

Figure 5: Shape of the Objective Function
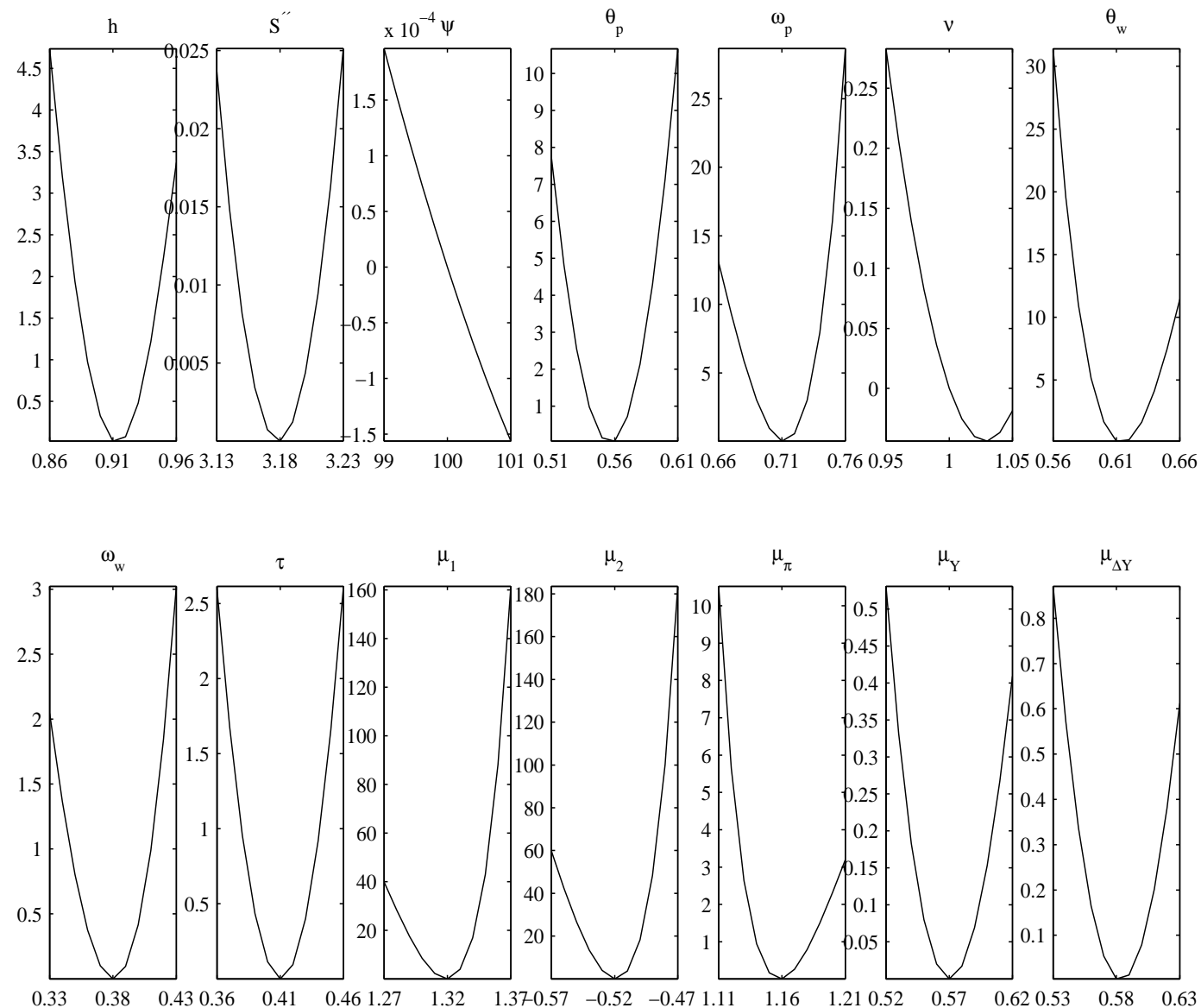

Notes: The vertical axis depicts the difference between the value of the objective function $J$ as a function of the parameter shown on the top of each graph, conditional on the other parameters being fixed at their baseline estimates, and the baseline value of the objective function $(J=53.70)$. The horizontal axis indicates the range, within which the parameters were varied in steps of 0.01 ( 0.2 in the case of $\psi$ ).

The only exceptions are the shapes of the objective function with respect to the the capital utilization parameter $\psi$ and the share of cost channel firms $\nu$. 
As both estimates hit the upper boundary of the constrained optimization, the objective function is falling in the neighborhood of the boundary. While the upper boundary of $\nu$ is binding as it defines a share of firms that cannot exceed 1 , the upper boundary for $\psi$ is less stringent. Theoretically, $\psi$ may go to infinity, implying that the rental rate of capital is fixed. ${ }^{21}$

Investigating the curvature of the objective function in one dimension is insufficient to guarantee that the optimization routine detects a global minimum in the constrained parameter space. If the objective function has ridges, flat regions or local minima, the vector of the parameter estimates $\varrho$ may depend on the vector of initial values $\varrho_{0}$. In order to properly identify the parameters we started the optimization routine 500 times from different initial conditions uniformly drawn within the ranges defined by the bounds of the constrained optimization. The histograms in Figure 6 show the densities of estimates, which are obtained after eliminating the 185 cases where either convergence failed, or the estimated parameters produced imaginary or indeterminate solutions. The figure on the top of each graph is the mode of the distribution of the estimated parameters. ${ }^{22}$

There are two interesting results that can be drawn from the histograms. First, the great majority of the estimates for $\psi$ and $\nu$ hit the upper boundary. Second, for the remaining parameters the distributions are very peaked with modes that are close to the baseline estimates of the structural parameters shown in Table 2. Such a distribution can be regarded as further evidence for properly identified parameters.

To gain further insight we ordered the vector of parameter estimates by the value of the distance function, starting with the lowest value. The lower right graph in Figure 7 shows that 251 out of 315 draws of initial values result in a value of the distance function equal to 53.70. The horizontal lines that can be found in all graphs indicate that these parameter estimates are associated with the minimum of the distance function. The figures on the top of each graph, which are the parameter estimates corresponding to the draw with the lowest value of the distance function, are identical with the parameter estimates shown

\footnotetext{
${ }^{21}$ Setting $\psi=1000$ reduces the value of the distance function from 53.70 to 53.68 , without changing any of the remaining parameter estimates.

${ }^{22}$ Here the mode is defined as the center of the bin of the histogram that contains the most frequently occurring estimate. In each histogram we set the number of bins equal to 50 . The bin width can be calculated as the difference between the upper and lower range divided by the number of bins. Hence, for a bin size of 50 the most frequently occurring estimate for $h$ is in the range of $0.92 \pm 0.01$, implying a bin width of 0.02 .
} 
Figure 6: Distribution of Estimates
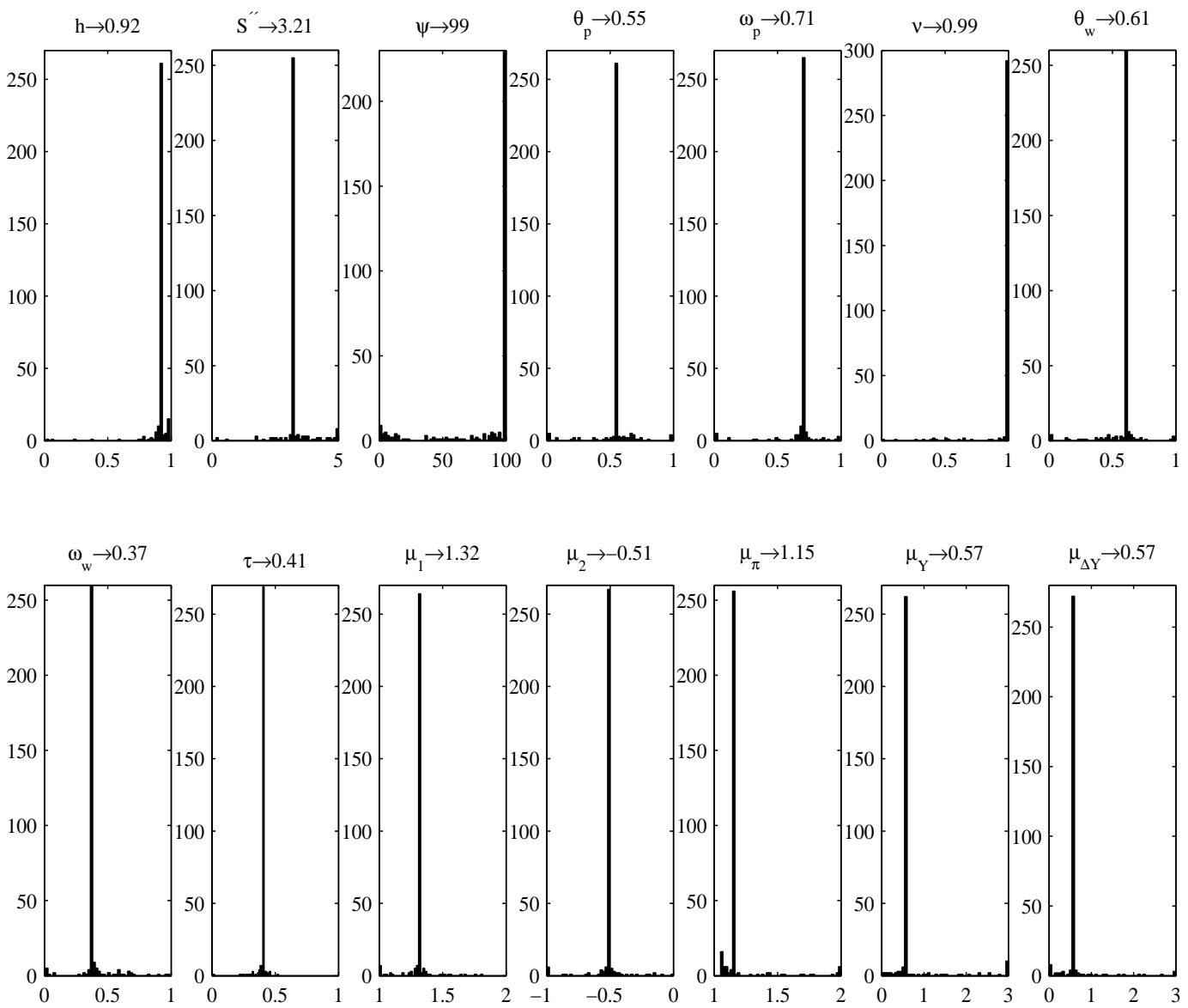

Notes: The histograms show the density of estimates obtained starting the optimization routine 500 times from different initial conditions uniformly drawn within the ranges considered on the horizontal axis. The figure on the top of each graph is the mode of the distribution of the estimated parameters. 
in Table 2. The graphs for $\psi$ and $\nu$ further show that in the constrained parameter space, the upper boundary is indeed associated with the minimum of the distance function.

Figure 7: Ordered Distribution of Estimates
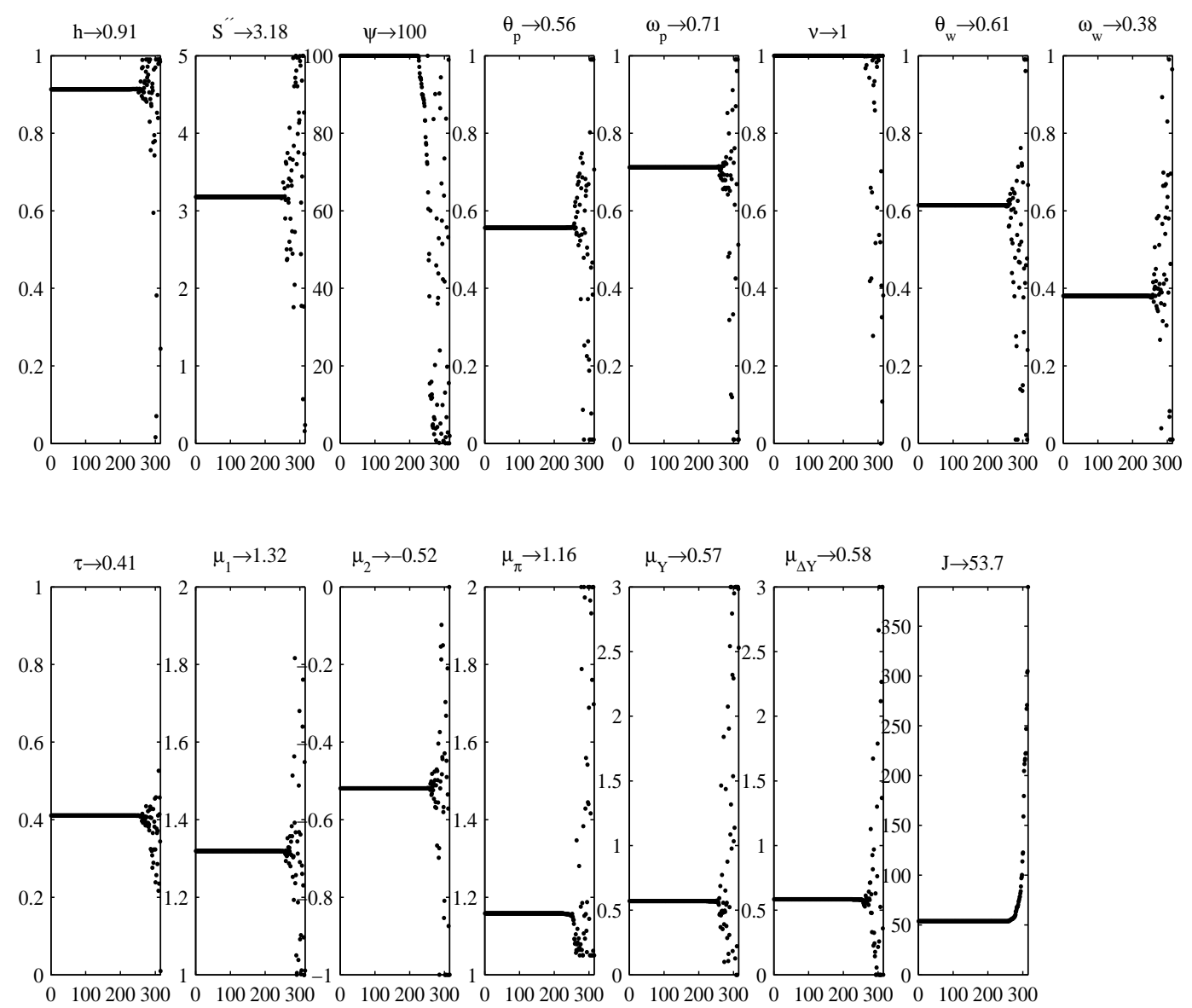

Notes: The vertical axis depicts the draws ordered by the value of the distance function, starting with the lowest value. The horizontal axis depicts the parameter estimates. The figure on the top of each graph is the parameter estimate corresponding to the draw with the lowest value of the distance function.

\section{Robustness against Variation of Calibrated Parameters}

When a subset of model parameters is calibrated, an important matter is whether the estimates of the remaining model parameters are robust against changes in the calibrated parameters. Figures 8 to 13 show the estimation results when one 
calibrated parameter was altered, conditional on the other calibrated parameters being fixed at their baseline values shown in Table 1 . The horizontal axes indicate the range, within which the calibrated parameter under consideration was varied. The range has been chosen so as to best represent the uncertainty about the parameters found in the literature (see Table 4). As initial values we took the parameter estimates of the baseline estimation (see Table 2).

Table 4: Values for Calibrated Parameters in the Literature

\begin{tabular}{lccccccc}
\hline \hline & $\beta$ & $\sigma$ & $\eta$ & $\phi$ & $\delta$ & $\alpha$ & $\epsilon$ \\
\hline Smets and Wouters (2003) & 0.99 & $\mathbf{1 . 6 1}$ & $\mathbf{1 . 1 9}$ & 3 & 0.025 & 0.3 & - \\
Del Negro et al. (2005) & 0.99 & 1 & $\mathbf{2 . 2 0}$ & 4.3 & 0.025 & $\mathbf{0 . 1 7}$ & 4.3 \\
Leith and Malley (2005) & $\mathbf{0 . 9 3}$ & $\mathbf{2 . 0 2}$ & 1.5 & 11 & - & 0.31 & 11 \\
Rabanal (2003) & 0.99 & $\mathbf{3 . 8 5}$ & 1 & 6 & - & 0.36 & 6 \\
Rabanal and Rubio-Ramirez (2003) & 0.99 & $\mathbf{5 . 8 8}$ & $\mathbf{1 . 6 4}$ & 6 & - & 0.36 & 6 \\
\hline \hline
\end{tabular}

Notes: All the papers cited in the Table estimated a DSGE model for the euro area with Bayesian techniques. The figures in the Table show the value of the calibrated parameters. If figures are in bold, the parameters have been estimated.

Except for some graphs in Figure 8 the parameter estimates depend monotonically on the calibrated parameters. If the degree of risk aversion $\sigma$ increases, the estimate of the investment adjustment costs $\bar{S}^{\prime \prime}$ falls and the central bank becomes more sensitive to movements in the inflation rate. The largest impact of the two parameters describing the households' supply of labor, $\eta$ and $\phi$, is on the wage setting rigidities, $\theta_{w}$ and $\omega_{w}$, which are decreasing functions of $\eta$ and $\phi$. Moreover, if $\eta$ increases, the estimate for the investment adjustment costs $\bar{S}^{\prime \prime}$ and for the degree of price stickiness $\theta_{p}$ increases, whereas the central bank's response to inflation $\mu_{\pi}$ decreases. The depreciation rate $\delta$ basically influences the estimate of the investment adjustment costs $\bar{S}^{\prime \prime}$, which become larger for a higher value of $\delta$. The production function parameter $\alpha$ has the broadest impact on the parameter estimates. The higher the capital share of output is, the lower is the estimated degree of habit formation $h$, the price rigidity parameters $\theta_{p}$ and $\omega_{p}$ and the central bank's response to output gap growth $\mu_{\Delta \hat{Y}}$, and the higher is the investment adjustment costs $\bar{S}^{\prime \prime}$, the wage setting rigidities $\theta_{w}$ and $\omega_{w}$, and the central bank's response to inflation $\mu_{\pi}$ and the output gap $\mu_{\hat{Y}}$. Variations of the inverse of the monopoly power of firms $\epsilon$ only affect the estimate of the investment adjustment costs $\bar{S}^{\prime \prime}$, which become larger for a higher value of $\epsilon$. 
Figure 8: Robustness of the Estimates against Variations of $\sigma$
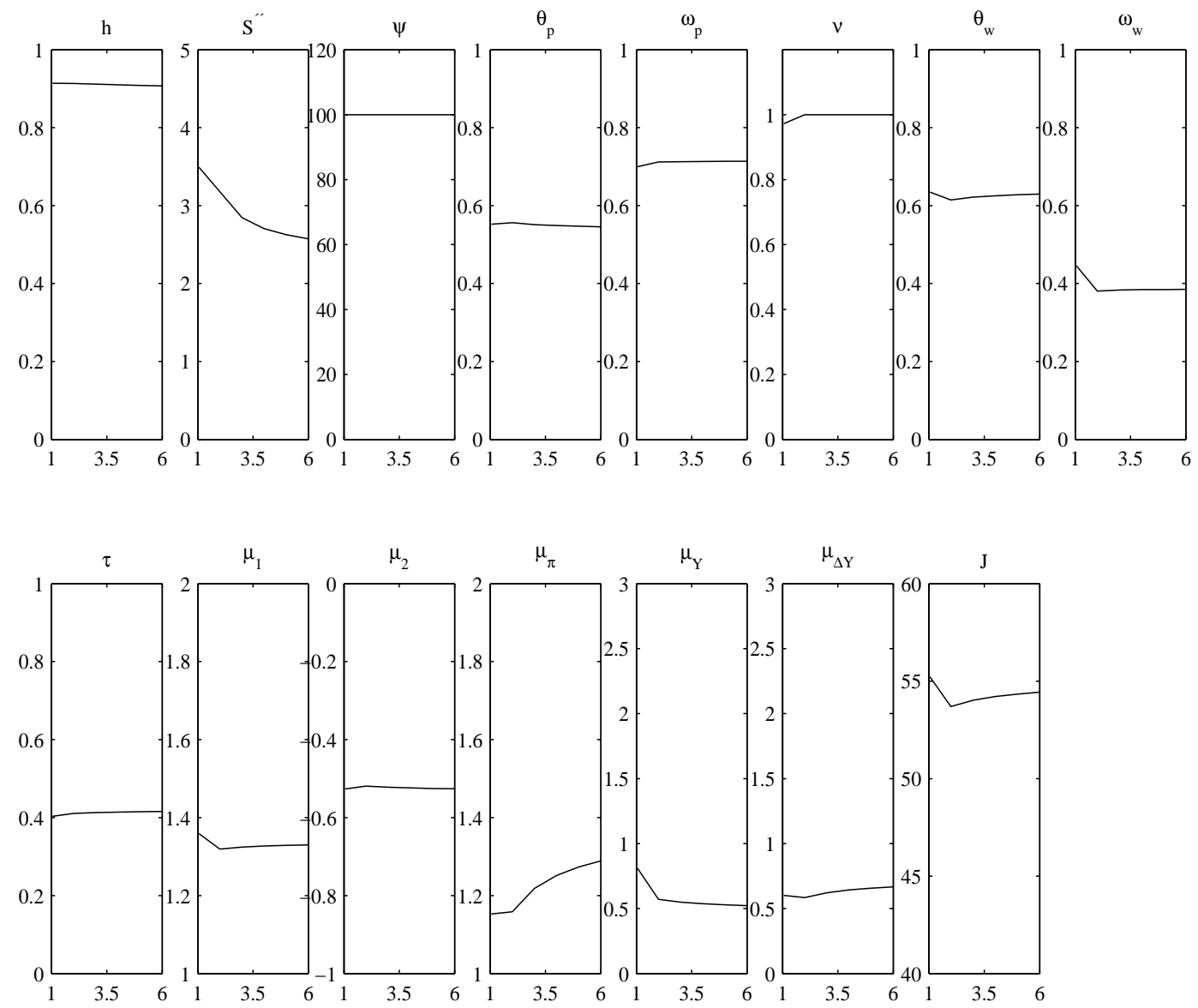
Figure 9: Robustness of the Estimates against Variations of $\eta$
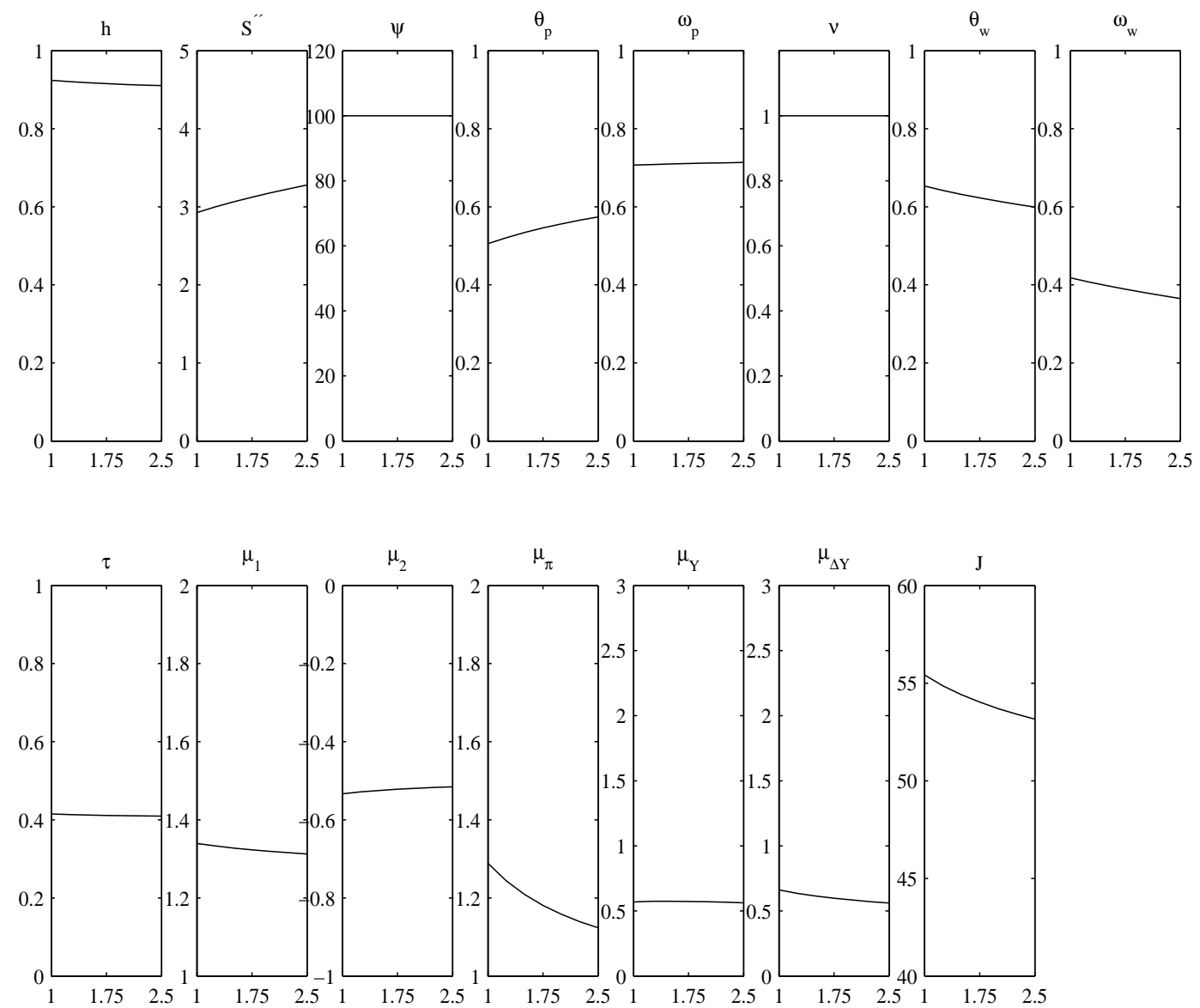
Figure 10: Robustness of the Estimates against Variations of $\phi$
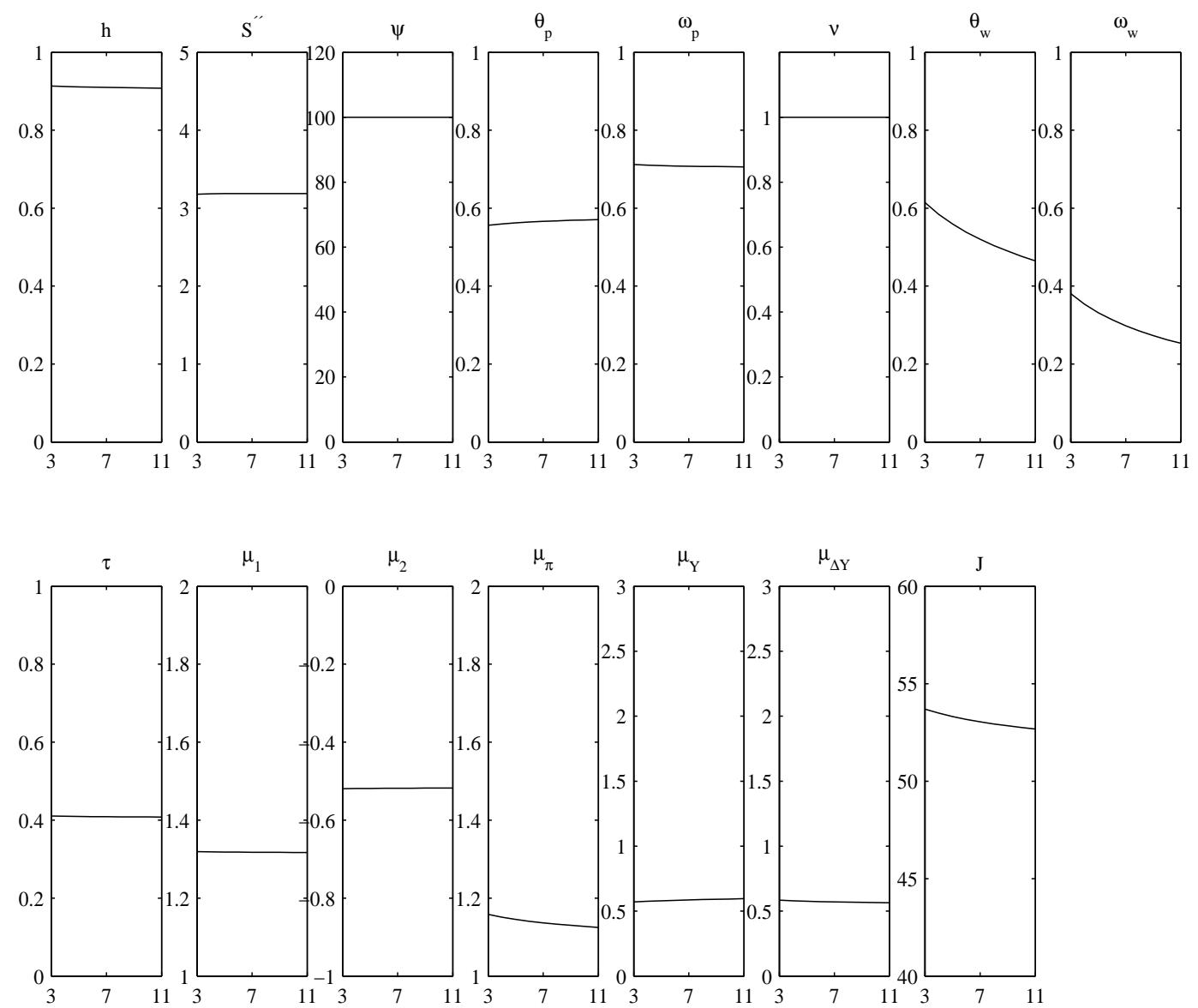
Figure 11: Robustness of the Estimates against Variations of $\delta$
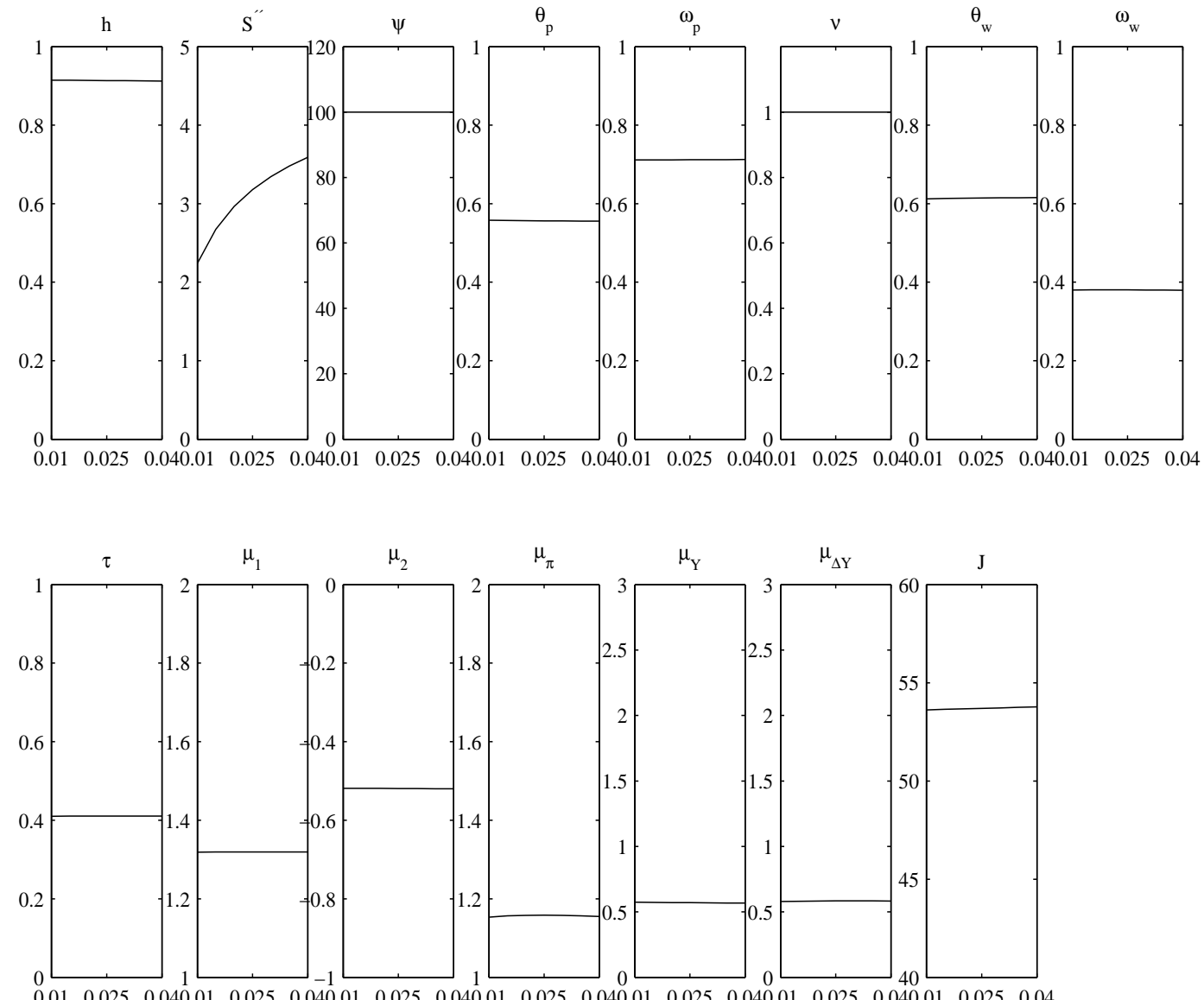
Figure 12: Robustness of the Estimates against Variations of $\alpha$
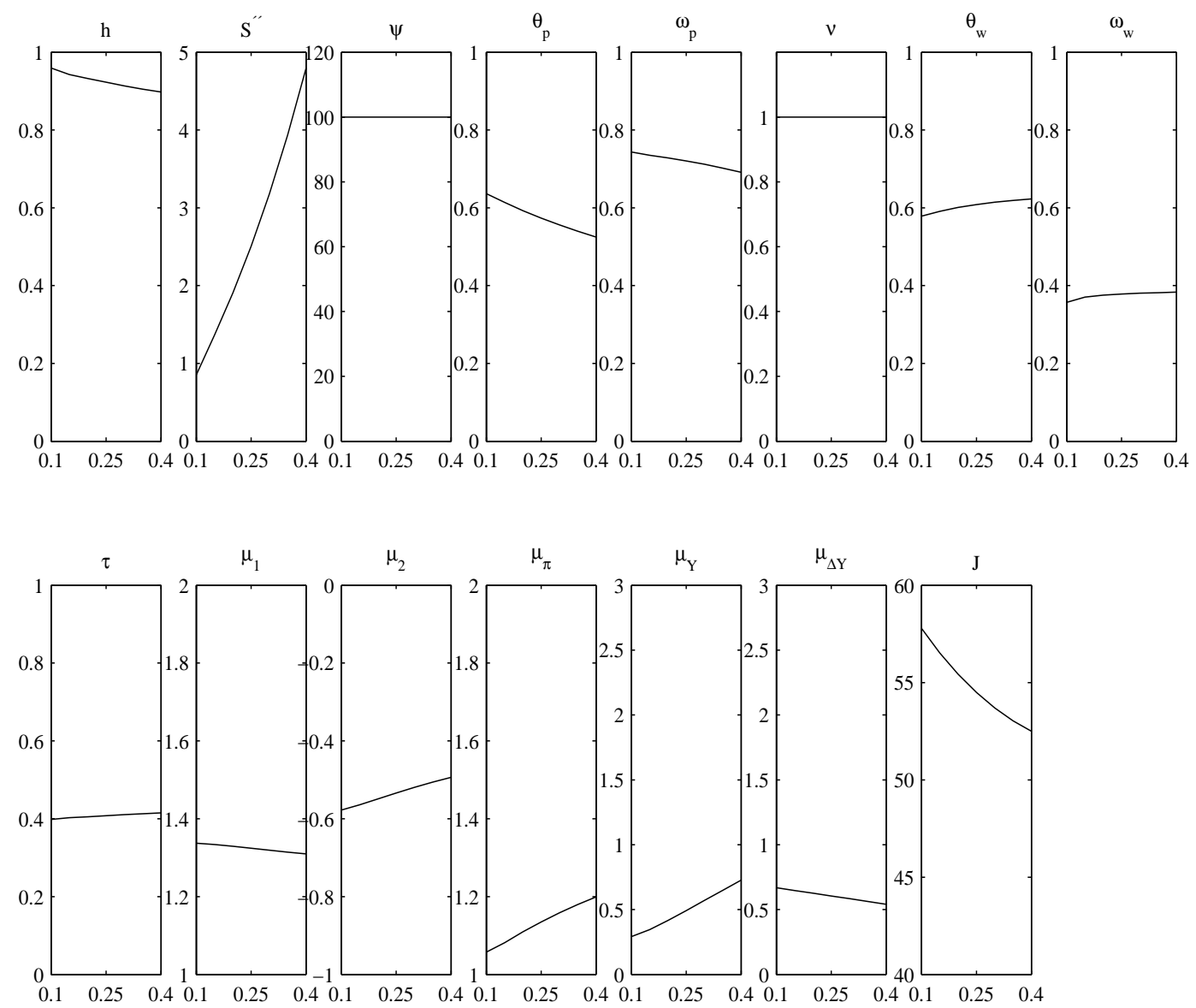
Figure 13: Robustness of the Estimates against Variations of $\epsilon$
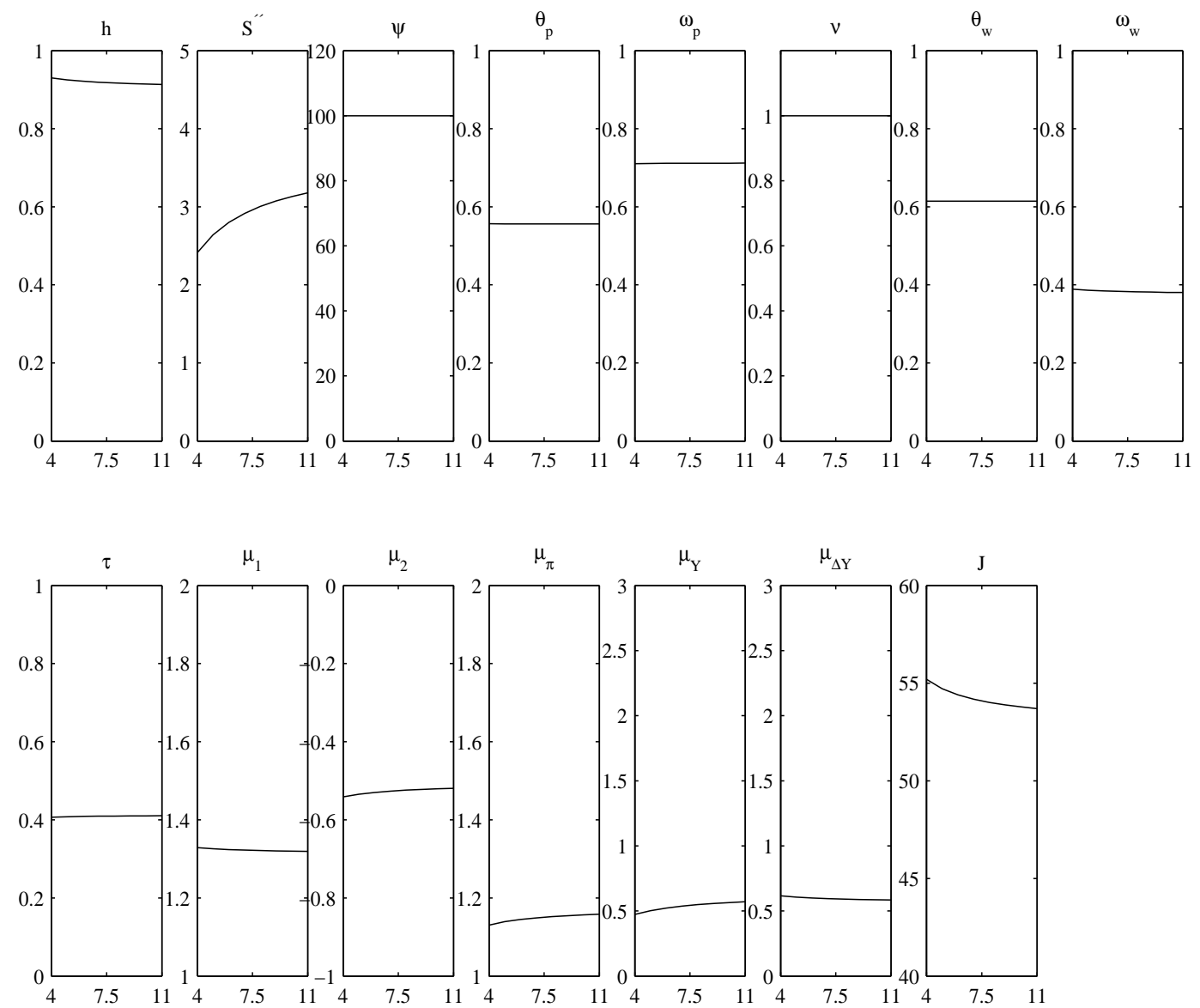


\section{References}

Altig, D., L. J. Christiano, M. Eichenbaum, and J. Linde (2005): "FirmSpecific Capital, Nominal Rigidities and the Business Cycle," Working Paper 11034, National Bureau of Economic Research.

Álvarez, L. J., E. Dhyne, M. Hoeberichts, C. Kwapil, H. Le Bihan, P. Lünnemann, F. Martins, R. Sabbatini, H. Stahl, P. Vermeulen, And J. Vilmunen (2006): "Sticky Prices in the Euro Area: A Summary of New Micro-Evidence," Journal of the European Economic Association, 4(2-3), $575-584$.

Barth, M. J., And V. A. Ramey (2000): "The Cost Channel of Monetary Transmission," Working Paper 7675, National Bureau of Economic Research.

Boivin, J., And M. P. Giannoni (2006): "Has Monetary Policy Become more Effective," The Review of Economics and Statistics, 88, 445-462.

Calvo, G. A. (1983): "Staggered Prices in a Utility-Maximizing Framework," Journal of Monetary Economics, 12, 383-398.

Canova, F., and L. Sala (2005): "Back to Square One: Identification Issues in DSGE Models," Working Paper 303, IGIER.

Carletti, E., P. Hartmann, and G. Spagnolo (2007): "Bank Mergers, Competition and Liquidity," Journal of Money, Credit and Banking, forthcoming.

Chowdhury, I., M. Hoffmann, and A. Schabert (2006): "Inflation Dynamics and the Cost Channel of Monetary Transmission," European Economic Review, 50, 995-1016.

Christiano, L. J., M. Eichenbaum, and C. Evans (1999): "Monetary Policy Shocks: What Have we Learned and to What End," in Handbook of Macroeconomics, ed. by J. B. Taylor, and M. Woodford, pp. 65-148, Amsterdam. Elsevier.

(2005): "Nominal Rigidities and the Dynamic Effects of a Shock to Monetary Policy," Journal of Political Economy, 113, 1-45. 
Coenen, G., P. McAdam, and R. Straub (2007): "Tax Reform and LabourMarket Performance in the Euro Area: A Simulation-Based Analysis Using the New Area-Wide Model," Working Paper 747, European Central Bank.

DE Bondt, G. J. (2005): "Interest Rate Pass-Through: Empirical Results for the Euro Area," German Economic Review, 6, 37-78.

Del Negro, M., F. Schorfheide, F. Smets, and R. Wouters (2005): "On the Fit and Forecasting Performance of New Keynesian Models," Working Paper 491, European Central Bank.

Eichenbaum, M. (1992): "Interpreting the Macroeconomic Time Series Facts: The Effects of Monetary Policy - Comments," European Economic Review, 36, 1001-1011.

Erceg, C. J., D. W. Henderson, and A. T. Levin (2000): "Optimal Monetary Policy with Staggered Wage and Price Contracts," Journal of Monetary Economics, 46, 281-313.

Fabiani, S., M. Druant, I. Hernando, C. Kwapil, B. Landau, C. Loupias, F. Martins, T. Mathä, R. Sabbatini, H. Stahl, and A. Stokman (2005): "The Pricing Behaviour of Firms in the Euro Area: New Survey Evidence," Working Paper 535, European Central Bank.

Fagan, G., J. Henry, and R. Mestre (2001): "An Area-Wide Model (AWM) for the Euro Area," Working Paper 42, European Central Bank.

Freixas, X., And J.-C. Rochet (1997): Microeconomics of Banking. MIT Press Cambridge, Massachusetts, Massachusetts.

Galí, J., M. Gertler, and J. D. López-Salido (2001): "European Inflation Dynamics," European Economic Review, 45, 1237-1270.

Giannoni, M. P., And M. Woodford (2005): "Optimal Inflation-Targeting Rules," in The Inflation Targeting Debate, ed. by B. S. Bernanke, and M. Woodford, pp. 93-162, Chicago. University of Chicago Press.

Hall, S. G. (1994): Applied Economic Forecasting Techniques. Harvester Wheatsheaf, New York. 
Hülsewig, O., E. Mayer, and T. Wollmershäuser (2006): "Bank Behavior and the Cost Channel of Monetary Transmission," Working Paper 1813, CESifo.

Leeper, E. M., C. A. Sims, and T. Zha (1996): "What Does Monetary Policy Do?," Brookings Papers on Economic Activity, 1996(2), 1-63.

Leith, C., And J. Malley (2005): "Estimated General Equilibrium Models for the Evaluation of Monetary Policy in the US and Europe," European Economic Review, 49, 2137-2159.

Meier, A., And G. Müller (2006): "Fleshing Out the Monetary Transmission Mechanism: Output Composition and the Role of Financial Frictions," Journal of Money, Credit, and Banking, 38(8), 2099-2134.

Nelson, E., J. Andrés, And D. López-Salido (2005): "Sticky-Price Models and the Natural Rate Hypothesis," Journal of Monetary Economics, 52, 10251053.

Rabanal, P. (2003): "The Cost Channel of Monetary Policy: Further Evidence for the United States and the Euro Area," Working Paper 149, International Monetary Fund.

(2007): "Does Inflation Increase after a Monetary Policy Tightening? Answers Based on an Estimated DSGE Model," Journal of Economic Dynamics and Control, 31, 906-937.

Rabanal, P., and J. F. Rubio-Ramirez (2003): "Comparing New Keynesian Models in the Euro Area: A Bayesian Approach," Working Paper 2003-30, Federal Reserve Bank of Atlanta.

Ravenna, F., And C. E. Walsh (2006): "Optimal Monetary Policy with the Cost Channel," Journal of Monetary Economics, 53, 199-216.

Rotemberg, J. J., And M. Woodford (1998): "An Optimization-Based Econometric Framework for the Evaluation of Monetary Policy: Expanded Version," Technical Working Paper 233, National Bureau of Economic Research.

Rudebusch, G., and M. Fuhrer (2005): "Estimating the Euler Equation for Output," Journal of Monetary Economics, 51, 1133-1353. 
Sims, C. A. (1992): "Interpreting the Macroeconomic Time Series Facts: The Effects of Monetary Policy," European Economic Review, 36, 975-1001.

(2001): "Solving Linear Rational Expectations Models," Computational Economics, 20, 1-20.

Smets, F., And R. Wouters (2003): "An Estimated Stochastic Dynamic General Equilibrium Model of the Euro Area," Journal of the European Economic Association, 1(5), 1123-1175.

Walsh, C. E. (2003): "Speed Limit Policies: The Output Gap and Optimal Monetary Policy," The American Economic Review, 93, 265-278.

Welz, P. (2006): "Assessing Predetermined Expectations in the Standard Sticky Price Model: A Bayesian Approach," Working Paper 621, European Central Bank. 


\section{CESifo Working Paper Series}

(for full list see www.cesifo-group.de)

1976 Andreas Haufler and Ian Wooton, Competition for Firms in an Oligopolistic Industry: Do Firms or Countries Have to Pay?, April 2007

1977 Eckhard Janeba, Exports, Unemployment and the Welfare State, April 2007

1978 Gernot Doppelhofer and Melvyn Weeks, Jointness of Growth Determinants, April 2007

1979 Edith Sand and Assaf Razin, The Role of Immigration in Sustaining the Social Security System: A Political Economy Approach, April 2007

1980 Marco Pagano and Giovanni Immordino, Optimal Regulation of Auditing, May 2007

1981 Ludger Woessmann, Fundamental Determinants of School Efficiency and Equity: German States as a Microcosm for OECD Countries, May 2007

1982 Bas Jacobs, Real Options and Human Capital Investment, May 2007

1983 Steinar Holden and Fredrik Wulfsberg, Are Real Wages Rigid Downwards?, May 2007

1984 Cheng Hsiao, M. Hashem Pesaran and Andreas Pick, Diagnostic Tests of Cross Section Independence for Nonlinear Panel Data Models, May 2007

1985 Luis Otávio Façanha and Marcelo Resende, Hierarchical Structure in Brazilian Industrial Firms: An Econometric Study, May 2007

1986 Ondřej Schneider, The EU Budget Dispute - A Blessing in Disguise?, May2007

1987 Sascha O. Becker and Ludger Woessmann, Was Weber Wrong? A Human Capital Theory of Protestant Economic History, May 2007

1988 Erkki Koskela and Rune Stenbacka, Equilibrium Unemployment with Outsourcing and Wage Solidarity under Labour Market Imperfections, May 2007

1989 Guglielmo Maria Caporale, Juncal Cunado and Luis A. Gil-Alana, Deterministic versus Stochastic Seasonal Fractional Integration and Structural Breaks, May 2007

1990 Cláudia Costa Storti and Paul De Grauwe, Globalization and the Price Decline of Illicit Drugs, May 2007

1991 Thomas Eichner and Ruediger Pethig, Pricing the Ecosystem and Taxing Ecosystem Services: A General Equilibrium Approach, May 2007

1992 Wladimir Raymond, Pierre Mohnen, Franz Palm and Sybrand Schim van der Loeff, The Behavior of the Maximum Likelihood Estimator of Dynamic Panel Data Sample Selection Models, May 2007 
1993 Fahad Khalil, Jacques Lawarrée and Sungho Yun, Bribery vs. Extortion: Allowing the Lesser of two Evils, May 2007

1994 Thorvaldur Gylfason, The International Economics of Natural Resources and Growth, May 2007

1995 Catherine Roux and Thomas von Ungern-Sternberg, Leniency Programs in a Multimarket Setting: Amnesty Plus and Penalty Plus, May 2007

1996 J. Atsu Amegashie, Bazoumana Ouattara and Eric Strobl, Moral Hazard and the Composition of Transfers: Theory with an Application to Foreign Aid, May 2007

1997 Wolfgang Buchholz and Wolfgang Peters, Equal Sacrifice and Fair Burden Sharing in a Public Goods Economy, May 2007

1998 Robert S. Chirinko and Debdulal Mallick, The Fisher/Cobb-Douglas Paradox, Factor Shares, and Cointegration, May 2007

1999 Petra M. Geraats, Political Pressures and Monetary Mystique, May 2007

2000 Hartmut Egger and Udo Kreickemeier, Firm Heterogeneity and the Labour Market Effects of Trade Liberalisation, May 2007

2001 Andreas Freytag and Friedrich Schneider, Monetary Commitment, Institutional Constraints and Inflation: Empirical Evidence for OECD Countries since the 1970s, May 2007

2002 Niclas Berggren, Henrik Jordahl and Panu Poutvaara, The Looks of a Winner: Beauty, Gender, and Electoral Success, May 2007

2003 Tomer Blumkin, Yoram Margalioth and Efraim Sadka, Incorporating Affirmative Action into the Welfare State, May 2007

2004 Harrie A. A. Verbon, Migrating Football Players, Transfer Fees and Migration Controls, May 2007

2005 Helmuth Cremer, Jean-Marie Lozachmeur and Pierre Pestieau, Income Taxation of Couples and the Tax Unit Choice, May 2007

2006 Michele Moretto and Paolo M. Panteghini, Preemption, Start-Up Decisions and the Firms' Capital Structure, May 2007

2007 Andreas Schäfer and Thomas M. Steger, Macroeconomic Consequences of Distributional Conflicts, May 2007

2008 Mikael Priks, Judiciaries in Corrupt Societies, June 2007

2009 Steinar Holden and Fredrik Wulfsberg, Downward Nominal Wage Rigidity in the OECD, June 2007 
2010 Emmanuel Dhyne, Catherine Fuss, Hashem Pesaran and Patrick Sevestre, Lumpy Price Adjustments: A Microeconometric Analysis, June 2007

2011 Paul Belleflamme and Eric Toulemonde, Negative Intra-Group Externalities in TwoSided Markets, June 2007

2012 Carlos Alós-Ferrer, Georg Kirchsteiger and Markus Walzl, On the Evolution of Market Institutions: The Platform Design Paradox, June 2007

2013 Axel Dreher and Martin Gassebner, Greasing the Wheels of Entrepreneurship? The Impact of Regulations and Corruption on Firm Entry, June 2007

2014 Dominique Demougin and Claude Fluet, Rules of Proof, Courts, and Incentives, June 2007

2015 Stefan Lachenmaier and Horst Rottmann, Effects of Innovation on Employment: A Dynamic Panel Analysis, June 2007

2016 Torsten Persson and Guido Tabellini, The Growth Effect of Democracy: Is it Heterogenous and how can it be Estimated?, June 2007

2017 Lorenz Blume, Jens Müller, Stefan Voigt and Carsten Wolf, The Economic Effects of Constitutions: Replicating - and Extending - Persson and Tabellini, June 2007

2018 Hartmut Egger and Gabriel Felbermayr, Endogenous Skill Formation and the Source Country Effects of International Labor Market Integration, June 2007

2019 Bruno Frey, Overprotected Politicians, June 2007

2020 Jan Thomas Martini, Rainer Niemann and Dirk Simons, Transfer Pricing or Formula Apportionment? Tax-Induced Distortions of Multinationals' Investment and Production Decisions, June 2007

2021 Andreas Bühn, Alexander Karmann and Friedrich Schneider, Size and Development of the Shadow Economy and of Do-it-yourself Activities in Germany, June 2007

2022 Michael Rauscher and Edward B. Barbier, Biodiversity and Geography, June 2007

2023 Gunther Schnabl, Exchange Rate Volatility and Growth in Emerging Europe and East Asia, June 2007

2024 Erkki Koskela and Ronnie Schöb, Tax Progression under Collective Wage Bargaining and Individual Effort Determination, June 2007

2025 Jay Pil Choi and Marcel Thum, The Economics of Politically Connected Firms, June 2007

2026 Jukka Pirttilä and Roope Uusitalo, Leaky Bucket in the Real World: Estimating Inequality Aversion Using Survey Data, June 2007 
2027 Ruslan Lukach, Peter M. Kort and Joseph Plasmans, Strategic R\&D with Knowledge Spillovers and Endogenous Time to Complete, June 2007

2028 Jarko Fidrmuc, Neil Foster and Johann Scharler, Labour Market Rigidities, Financial Integration and International Risk Sharing in the OECD, June 2007

2029 Bernardina Algieri and Thierry Bracke, Patterns of Current Account Adjustment Insights from Past Experience, June 2007

2030 Robert Dur and Hein Roelfsema, Social Exchange and Common Agency in Organizations, June 2007

2031 Alexander Libman and Lars P. Feld, Strategic Tax Collection and Fiscal Decentralisation: The Case of Russia, June 2007

2032 Øystein Foros, Hans Jarle Kind and Greg Shaffer, Resale Price Maintenance and Restrictions on Dominant Firm and Industry-Wide Adoption, June 2007

2033 Jan K. Brueckner and Kurt Van Dender, Atomistic Congestion Tolls at Concentrated Airports? Seeking a Unified View in the Internalization Debate, June 2007

2034 Viet Do and Ngo Van Long, International Outsourcing under Monopolistic Competition: Winners and Losers, June 2007

2035 Nadia Fiorino and Roberto Ricciuti, Determinants of Direct Democracy, June 2007

2036 Burkhard Heer and Alfred Maussner, Inflation and Output Dynamics in a Model with Labor Market Search and Capital Accumulation, June 2007

2037 Konstantinos Angelopoulos, Jim Malley and Apostolis Philippopoulos, Public Education Expenditure, Growth and Welfare, June 2007

2038 Maarten Bosker, Steven Brakman, Harry Garretsen and Marc Schramm, Adding Geography to the New Economic Geography, June 2007

2039 Steffen Henzel, Oliver Hülsewig, Eric Mayer and Timo Wollmershäuser, The Price Puzzle Revisited: Can the Cost Channel Explain a Rise in Inflation after a Monetary Policy Shock?, July 2007 